\title{
Target-Specific Vulnerability of Excitatory Synapses Leads to Deficits in Associative Memory in a Model of Intellectual Disorder
}

\author{
Xander Houbaert, ${ }^{1 \star}$ Chun-Lei Zhang, ${ }^{1 *}$ Frédéric Gambino, ${ }^{2}$ Marilyn Lepleux, ${ }^{1}$ Melissa Deshors, ${ }^{1,3}$ Elisabeth Normand, ${ }^{3}$ \\ Florian Levet, ${ }^{4}$ Mariana Ramos, ${ }^{5}$ Pierre Billuart, ${ }^{5}$ Jamel Chelly, ${ }^{5}$ Etienne Herzog, ${ }^{1}$ and Yann Humeau ${ }^{1}$ \\ ${ }^{1}$ Team synapse in cognition, Institut Interdisciplinaire de Neuroscience, Centre National de la Recherche Scientifique CNRS UMR5297, Université de \\ Bordeaux, 33077 Bordeaux, France, ${ }^{2}$ Institut des neurosciences cellulaires et intégratives, Centre National de la Recherche Scientifique CNRS UPR3212, \\ Université de Strasbourg, 67000 France, ${ }^{3}$ Pole in vivo, Institut Interdisciplinaire de Neuroscience, Centre National de la Recherche Scientifique CNRS \\ UMR5297, Université de Bordeaux, 33077 Bordeaux, France, ${ }^{4}$ Team imaging the cell, Institut Interdisciplinaire de Neuroscience, Centre National de la \\ Recherche Scientifique CNRS UMR5297, Université de Bordeaux, 33077 Bordeaux, France, and ${ }^{5}$ Centre National de la Recherche Scientifique, Université \\ Paris Descartes, Institut National de la Santé et de la Recherche Médicale, UMR8104, Institut Cochin, 75014 Paris, France
}

Intellectual disorders (IDs) have been regularly associated with morphological and functional deficits at glutamatergic synapses in both humans and rodents. How these synaptic deficits may lead to the variety of learning and memory deficits defining ID is still unknown. Here we studied the functional and behavioral consequences of the ID gene illrapll deficiency in mice and reported that illrapl1 constitutive deletion alters cued fear memory formation. Combined in vivo and in vitro approaches allowed us to unveil a causal relationship between a marked inhibitory/excitatory $(\mathrm{I} / \mathrm{E})$ imbalance in dedicated amygdala neuronal subcircuits and behavioral deficits. Cell-targeted recordings further demonstrated a morpho-functional impact of the mutation at thalamic projections contacting principal cells, whereas the same afferents on interneurons are unaffected by the lack of Ill rapll. We thus propose that excitatory synapses have a heterogeneous vulnerability to ill rapll gene constitutive mutation and that alteration of a subset of excitatory synapses in neuronal circuits is sufficient to generate permanent cognitive deficits.

\section{Introduction}

Learning-related forms of persisting synaptic plasticity (LTP) at excitatory synapses were initially discovered in the hippocampus (Bliss and Lomo, 1973). Although diverse in their molecular and cellular mechanisms, LTP has now been found in most brain areas, including amygdala (Rumpel et al., 2005). Meanwhile, $>450$ gene mutations have been identified as causing intellectual disorders (IDs) (van Bokhoven, 2011). Studies on human and animal models consistently reported that ID gene mutations pri-

\footnotetext{
Received April 3, 2013; revised July 20, 2013; accepted July 23, 2013

Author contributions: J.C. and Y.H. designed research;X.H., C.-L.Z., F.G., M.L., M.D., E.N., P.B., and Y.H. performed research; F.L., M.R., and P.B. contributed unpublished reagents/analytic tools; X.H., C.-L.Z., F.G., M.L., and Y.H. analyzed data; E.H. and Y.H. wrote the paper.

This work was supported by Agence Nationale pour la Recherche (J.C., E.H., and Y.H.), the European Neuroscience Institutes Network (Y.H.), and the Gencodys FP7 program (Y.H. and J.C.). We thank Drs Shona Osborne, Cyril Herry, Andréas Lüthi, Julien Dupuis, and François Georges for their critical reading of the manuscript; Dr. Jiyun Peng for helping in the tracking of mouse activities; and the Pole In Vivo and animal facilities of the Bordeaux University for the animal care. The microscopy was done at the Bordeaux Imaging Center of the University of Bordeaux Segalen, with the help of Sébastien Marais and Magali Mondin.

The authors declare no competing financial interests.

${ }^{*}$ X.H. and C.-L.Z. contributed equally to this work.

Correspondence should be addressed to Dr. Yann Humeau, UMR5297 Institut Interdisciplinaire de Neuroscience, Centre de génomique fonctionnelle, 146 rue Léo Saignat, 33077, Bordeaux cedex, France. E-mail: yann.humeau@u-bordeaux2.fr.

F. Gambino's present address: Département des neurosciences fondamentales, CMU, Genève, Suisse.

DOI:10.1523/JNEUROSCI.1457-13.2013

Copyright $\odot 2013$ the authors $\quad 0270-6474 / 13 / 3313805-15 \$ 15.00 / 0$
}

marily impact the morphology and/or function of excitatory synapses (Purpura, 1974). Remarkably, deficits in LTP in ID models remain poorly documented (Vaillend et al., 2008; Humeau et al., 2009), although an increasing number of ID gene products are involved in LTP-relevant signaling pathways (Pavlowsky et al., 2011).

In mammals, pairing an initially neutral stimulus (conditioned stimulus [CS]) with an aversive stimulus (unconditioned stimulus [US]) leads to the formation of a robust and long-lasting associative fear memory (Ledoux, 2000). During CS/US associations, long-lasting synaptic potentiation is induced at excitatory synapses impinging onto principal cells of the lateral nucleus of the amygdaloid complex (LA) (Rumpel et al., 2005; Humeau et al., 2007). Interestingly, the gating of this form of LTP is only possible in conditions lowering the influence of feedforward GABAergic inhibition (Bissière et al., 2003; Ehrlich et al., 2009), implying that a functional adaptation of the inhibition/excitation (I/E) balance is required to allow suprathreshold, postsynaptic depolarization during fear conditioning. Moreover, I/E balance alterations have been recurrently associated with neurological and ID animal models (Kleschevnikov et al., 2004; Dani et al., 2005; Baroncelli et al., 2011; Pizzarelli and Cherubini, 2011; Yizhar et al., 2011), including ill rapll mutant mice (Gambino et al., 2009).

In humans, ill rapll mutation leads to a spectrum of cognitive defects, ranging from nonsyndromic intellectual disorders to au- 
tistic spectrum disorders (ASDs) (Piton et al., 2008). Illrapll is a member of a novel family of IL1/Toll receptors enriched at excitatory synapses (Pavlowsky et al., 2010). Il1rapl1 induces excitatory presynapse formation by interacting trans-synaptically with the protein tyrosine phosphatase $\delta(\mathrm{PTP} \delta$ ) (Valnegri et al., 2011; Yoshida et al., 2011) but also interacts with some components of the postsynaptic density, such as PSD95, RhoGAP2, and Mcf2l (Pavlowsky et al., 2010; Valnegri et al., 2011; Hayashi et al., 2013), enabling morphological and functional maintenance of excitatory dendritic spines and glutamate receptor insertion (Hayashi et al., 2013). Illrapll also regulates N-type voltagegated calcium channel and neurite elongation in neuroendocrine cells through its interaction with the neuronal calcium sensor-1 (Gambino et al., 2007). Thus, current data support the notion that Il1rapl1 is important for the formation, maintenance, and function of excitatory synapses by converging presynaptic, postsynaptic, and trans-synaptic effects.

Yet, the consequences of ill rapll deletion onto physiological properties of mature neuronal networks and related behavioral paradigms remain unexplored. Here we identified an I/E imbalance in the amygdala circuits of adult ill rapll constitutive mutant mice, resulting from a heterogeneous vulnerability of excitatory synapses to Il1rapl1 removal. We then determined how these functional perturbations of amygdala circuit impact fear memory formation.

\section{Materials and Methods \\ Animals}

Most experiments were performed using male il1 rapl1 - $/ y$ and their control $+/ y$ littermates (2-3 months old, C57BL/6 background), housed in 12/12 LD with ad libitum feeding. Some crossings with GAD67-eGFP mice (Tamamaki et al., 2003) (kindly provided by A. Lüthi's laboratory, FMI, Basel, Switzerland) were made in house to allow visualizing amygdala interneurons. Every effort was made to minimize the number of animals used and their suffering. The experimental design and all procedures were in accordance with the European guide for the care and use of laboratory animals and the animal care guidelines issued by the animal experimental committee of Bordeaux Universities (CE50; A5012009).

\section{Fear conditioning}

Mice were housed individually in a ventilation area before the start of behavioral training. Animals were handled every day before the start of the experiment during a week. On day 1 , animals were transferred to the conditioning context (Context A) for habituation. Both $\mathrm{CS}^{+}$(total CS duration of $30 \mathrm{~s}$, consisting of $50 \mathrm{~ms}$ pips repeated at $0.9 \mathrm{~Hz}$, pip frequency $7.5 \mathrm{kHz}, 80 \mathrm{~dB}$ sound pressure level) and $\mathrm{CS}^{-}(30 \mathrm{~s}$, consisting of white noise pips repeated at $0.9 \mathrm{~Hz}, 80 \mathrm{~dB}$ sound pressure level) were presented 4 times with a variable interstimulus interval (ISI). On day 2 , we proceeded with the conditioning phase. The protocol consisted of 5 pairings of $\mathrm{CS}^{+}$with the US onset coinciding with the $\mathrm{CS}^{+}$offset $(1 \mathrm{~s}$ foot shock, $0.6 \mathrm{~mA}$, ISI $10-60 \mathrm{~s}$ ). In all cases, $\mathrm{CS}^{-}$presentations were intermingled with $\mathrm{CS}^{+}$presentations and ISI was variable over the whole training course. Cued memory was tested $24 \mathrm{~h}$ after conditioning by analyzing the freezing levels at the first $\mathrm{CS}^{+}$presentations in Context $\mathrm{B}$ (recall). Freezing behavior was quantified automatically in each behavioral session using a fire-wire CCD camera (Ugo Basile) connected to automated freezing detection software (ANY-maze, Stoelting). To test for animal exploration and activity, the animal displacement in the context was traced and analyzed with software programmed and provided by Dr. Jiyun Peng (Fudan, Shanghai, China).

\section{Electrophysiology}

Slice preparation. Standard procedures were used to prepare 300 - to 330$\mu \mathrm{m}$-thick coronal slices from 4 -week-old up to 2.5 -month-old male wild-type or mutant mice following a protocol approved by the European and French guidelines on animal experimentation. Briefly, the brain was dissected in ice-cold artificial CSF (ACSF) containing the following (in mM): $124 \mathrm{NaCl}, 2.7 \mathrm{KCl}, 2 \mathrm{CaCl}_{2}, 10 \mathrm{MgSO}_{4}, 7 \mathrm{H}_{2} \mathrm{O}, 26$ $\mathrm{NaHCO}_{3}, 1.25 \mathrm{NaH}_{2} \mathrm{PO}_{4}, 18.6$ glucose, and 2.25 ascorbic acid; the brain was mounted against an agar block and sliced with a vibratome (Leica VT1200 s) at $4^{\circ} \mathrm{C}$. Slices were maintained for $45 \mathrm{~min}$ at $37^{\circ} \mathrm{C}$ in an interface chamber containing ACSF equilibrated with $95 \% \mathrm{O}_{2} / 5 \% \mathrm{CO}_{2}$ and then for at least $45 \mathrm{~min}$ at room temperature before being transferred to a superfusing recording chamber. In the perfused ACSF, the $\mathrm{MgSO}_{4}$ was decreased to $1.3 \mathrm{~mm}$.

Recordings. Whole-cell recordings from LA principal neurons were performed at $30-32^{\circ} \mathrm{C}$ in a superfusing chamber as previously described (Humeau et al., 2005). Neurons were visually identified with infrared videomicroscopy using an upright microscope equipped with a $60 \times$ objective. Patch electrodes (3-5 M $\Omega$ ) were pulled from borosilicate glass tubing and filled with a low-chloride solution containing the following (in mM): 140 Cs-methylsulfonate, 5 QX314 Cl, 10 HEPES, 10 phosphocreatine, $4 \mathrm{Mg}$-ATP, and $0.3 \mathrm{Na}-\mathrm{GTP}$ (pH adjusted to 7.25 with $\mathrm{CsOH}, 300 \mathrm{mOsm})$. For dedicated current-clamp experiments, Cs-methylsulfonate was replaced with equimolar K-gluconate. All LTP experiments were performed in the presence of picrotoxin $(100 \mu \mathrm{M})$, except the no-PTX experiments shown in Figure 2. Monosynaptic EPSCs or EPSPs exhibiting constant $10-90 \%$ rise times and latencies were elicited by stimulation of afferent fibers with a bipolar twisted platinum $/ 10 \%$ iridium wire ( $25 \mu \mathrm{m}$ diameter). In all experiments, stimulation intensity was adjusted to obtain baseline EPSC amplitudes between 100 and 200 pA (CC mode) or 4-6 mV (IC mode). In some experiments, the capacitance of recorded cells was measured to evaluate the cell size. We used an exponential fit adjusted to the capacitive current generated by $100 \mathrm{~ms} / 10$ $\mathrm{mV}$ hyperpolarizing steps under the voltage-clampmode (see Fig. 4, seal tests).

LA interneuron classification. GAD-67-eGFP-expressing interneuron separation was based on the spiking patterns of recorded cells. To elicit spikes, cells were maintained at $-70 \mathrm{mV}$ in current-clamp mode and submitted to repeated, 400-ms-long, current steps of increasing intensity: $-50,50,150,250$, and $350 \mathrm{pA}$, to explore a variety of potential response. In most cases, spiking inactivation was seen at the end of high intensity trains, indicating that the cell has reached its maximal spiking capacity. Otherwise, additional current injections of greater intensities were applied to reach spike inactivation. The last current step not inducing spike inactivation was retained for analysis. We analyzed neuronal discharge by measuring each spike amplitude and interspike intervals (ISI) observed during the train. IN classification was essentially based on the number of observed spikes (REG $>$ BIM $>$ ADA $>$ SADA) and the degree of spike adaptation (last ISI/first ISI: BIM $>$ ADA, SADA $>$ REG). Occasionally, we also used spike half-width (REG $<$ BIM $<$ ADA, SADA) and the initial spike frequency (BIM > SADA, ADA, REG) to allow classifying some borderline cases.

Data acquisition and analysis. Data were recorded with a Multiclamp700B (Molecular Devices), filtered at $2 \mathrm{kHz}$ and digitized at $10 \mathrm{kHz}$. Data were acquired and analyzed with pClamp10.2 (Molecular Devices). In all experiments, series resistance was monitored throughout the experiment; and if it changed by $>15 \%$, the data were not included in the analysis. Changes were quantified by normalizing and averaging EPSP slope during the last $5 \mathrm{~min}$ of the experiments relative to the $5 \mathrm{~min}$ of baseline before LTP induction or drug application.

\section{Morphological analysis}

In situ hybridization of ill rapl1 mRNA. This protocol was performed by a service company (Oramacell). Detection of each mRNA (VGLUT1, solute carrier family 17, member 7, slc17a7; NM_182993), glutamate decarboxylase 1 (gad1; NM_008077), and interleukin 1 receptor accessory protein-like 1 (il1rapl1; NM_001160403.1) was achieved by design of antisense oligonucleotides using Helios ETC oligo design software (Oramacell). For il1 rapl1 mRNA detection, two sets of oligonucleotides were designed: one specific for exon 5 (2 oligonucleotides) and one nonspecific of exon 5 ( 5 oligonucleotides). For slc17a7 and gad 1 mRNA detection, a set of 3 oligonucleotides was designed for mRNA. Each oligonucleotide and a mix of two or three labeled oligonucleotides were tested for the hybridization step. Same results were obtained for each 
mRNA for the four probes. In situ hybridization was performed as described previously (Moutsimilli et al., 2005). Briefly, oligonucleotides were labeled with $\left[{ }^{35} \mathrm{~S}\right]$-dATP using terminal transferase to a specific activity of $5 \times 10^{8} \mathrm{dpm} / \mu \mathrm{g}$. Experimental slides were fixed in $4 \%$ formaldehyde in PBS, washed with PBS, rinsed with water, dehydrated in $70 \%$ ethanol, and air-dried. Sections were then covered with $140 \mu \mathrm{l}$ of a hybridization medium (Oramacell) containing 3-5 $\times 10^{5} \mathrm{dpm}$ of the labeled oligonucleotide mix. Slides were incubated overnight at $42^{\circ} \mathrm{C}$, washed, and exposed to a BAS-SR Fujifilm Imaging Plate for $15 \mathrm{~d}$. The plates were scanned with a Fujifilm BioImaging Analyzer BAS-5000 and analyzed with MultiGauge software. Slides were then dipped in Kodak NTB emulsion, exposed for 6 weeks, developed and counterstained with toluidine blue.

Neurobiotin-based dendritic spine analysis. Amygdala-containing coronal sections ( $300 \mu \mathrm{m}$ thick) in which LA principal cells were loaded with neurobiotin $(0.02 \%$ in intracellular medium) for at least $20 \mathrm{~min}$ in open whole-cell configuration were first fixed in PFA $10 \%$ and then treated with PBS solution containing Triton $0.4 \%$ and $33 \mathrm{~mm} \mathrm{NaH}_{4} \mathrm{Cl}$ to block PFA aldehydic functions. Neurobiotin was then revealed using streptavidin-conjugated with AlexaFluor-568. Sections were then coverslipped with Vectashield, and $z$-stack images performed using confocal microscopy (Leica SP2, 63× oil-immersion objective) with a lateral resolution of $\sim 200 \mathrm{~nm}$. Spine number, spine length, spine head diameter, and spine type (mushroom, thin, stubby) were analyzed using Neuron Studio software (Rodriguez et al., 2008) (http://research.mssm. edu/cnic/tools.html). The first step consists of adjusting settings and software calibration to automatically detect dendritic spines. In all cases, automatic results were manually checked on the 3D reconstruction to delete false-positive and add nondetected spines. Values for each branch segment were expressed as spine number/ $\mu \mathrm{m}$.

Presynaptic and postsynaptic apposed clusters analysis. To prepare amygdala coronal sections, 3 and 3 Ill rapll $+/ y$ and $-/ y$ mice were anesthetized with pentobarbital and fixed by intracardiac perfusion with $4 \%$ paraformaldehyde in PBS. The brains were dissected, postfixed during $24 \mathrm{~h}$, and coronal, 50- $\mu \mathrm{m}$-thick sections were obtained using a vibratome (Leica $1200 \mathrm{~s}$ ). The brain sections were maintained in a blocking buffer (PBS solution containing $0.3 \%$ Triton X-100 and 2\% gelatin) for $1 \mathrm{~h}$ at room temperature. Thereafter, sections were incubated at $4^{\circ} \mathrm{C}$ overnight with monoclonal antibody against PSD95 (1:600; Abcam, ab2723) and polyclonal antibodies against VGlut2 $(1: 10,000)$ from Millipore (AB2251) diluted in the blocking buffer. Slices were rinsed three times in PBS and incubated for $2 \mathrm{~h}$ at room temperature with Alexa488and Alexa647-labeled goat anti-mouse or anti-guinea pig Ig G secondary antibodies (1:1000, Invitrogen), rinsed in PBS before being mounted with Vectashield.

Amygdala $z$-stacks were captured with confocal microscope (Leica SPE, $63 \times$ oil-immersion objective), at a constant depth from the surface. To compute apposition between the presynaptic and the postsynaptic staining, a plugin developed within ImageJ and based on wavelets transform was used to perform image processing and analysis. At first, each staining is segmented (by the use of "à trous" wavelets, see below) in a set of objects. Afterward, these two segmentations were used in a pixel-based technique to determine their appositions.

Segmentation. The input signal (i.e., the image) is analyzed by using the coefficients of a low-pass filter. Because wavelets are a multiresolution representation, the low-pass filter was stretched depending on the resolution level. As a result, each resolution level generated a different set of coefficients. To filter unwanted background noise while keeping details of interest, it was sufficient to directly set the threshold for the wavelet coefficient sub-bands in which the size of the filter is close to the size of the desired objects (in our case, there were the two first ones). Results of this filtering were two binary images (one for each staining) with clusters being identified as individual objects.

Apposition. To determine whether the presynaptic staining was apposed to the postsynaptic one at a given location, each cluster was tagged with a value: 0 for background, 1 for presynaptic, and 2 for postsynaptic clusters. A new image was created, which is the result of the addition of all the presynaptic and postsynaptic clusters. Once all the objects of this image were identified, we could easily determine whether there were apposed clusters. If an object was not composed of a single value (either 1 or 2), then it was an apposed cluster. Two cases were possible: if the two objects were touching themselves with no overlapping pixels, they were perfectly apposed. On the contrary, if some overlapping pixels were present, the objects were just apposed. In this study, all apposed events were counted. Because the technique is pixel-based, apposition was determined at the resolution level of the images.

\section{Cannula implantation and drug administration}

Cannula implantation. Stainless steel guide cannula (26 gauge; PlasticsOne) were bilaterally implanted above amygdala under continuous anesthesia with isoflurane. Beforehand, mice were treated with buprenorphine $(0.1 \mathrm{mg} / \mathrm{kg}$, i.p) and positioned in a stereotaxic apparatus (David Kopf Instruments). The positions of bregma and $\lambda$ points were defined and adjusted to the same horizontal level. Coordinates were as follows: LA, anteroposterior, $-1.7 \mathrm{~mm}$, mediolateral, $\pm 3.1 \mathrm{~mm}$, and dorsoventral, $-2.8-3 \mathrm{~mm}$. Cannula was secured to the skull using dental cement (Super-Bond, Sun Medical). In the end, the mice woke up on a $35^{\circ} \mathrm{C}$ heating pad, and a dummy cannula was inserted into the guide cannula to reduce the risk of infection.

Drug administration. To reduce stress during drug injection, the mice were trained with dummy cannula removal and insertion 1 week before use. To perform freely moving drug injection, the dummy cannula was replaced by an infusion cannula ( 33 gauge; connected to a $1 \mu$ l Hamilton syringe via polyethylene tubing) projecting out of the guide cannula with $1 \mathrm{~mm}$ to target LA. As previously described (Herry et al., 2008), the GABA-A receptor antagonist bicuculline $(20 \mathrm{ng} / 200 \mathrm{nl}$ in saline) was infused bilaterally at a rate of $0.1 \mu \mathrm{l} / \mathrm{min}$ in a volume of $200-250 \mathrm{nl}$ per side by an automatic pump (Legato 100, Kd Scientific) 30-60 min before learning. To allow penetration of drug, the injector was maintained for an additional $3 \mathrm{~min}$. After injection, mice were put back in the cages before behavioral testing. Importantly, no seizures were observed upon bicuculline treatment in all cohorts analyzed and presented here.

Controls. To analyze the location and extent of the injections, brains were injected with a fluorophore BODIPY TMR-X (Invitrogen; $5 \mathrm{~mm}$ in PBS $0.1 \mathrm{~m}$, DMSO 40\%). Then slices $(60 \mu \mathrm{m})$ were imaged using a $5 \times$ epifluorescence microscope (Leica DM5000). The mice we considered for further analysis had at least one side precisely targeted above the LA and where each side was covered by $>25 \%$ bodipy fluorescence.

\section{Freely moving optical stimulation}

AAV injections: adeno-associated viruses. AAV constructs and viruses were obtained from the U-penn Vector Core. We used AAV2/9 vectorsencodingforChR2-Venusexpression(AAV2/9.CAG.ChR2-Venus. W.SV40) (Addgene ref. 20071; 5.82 $\mathrm{E}^{12}$ vector genomes, $\mathrm{vg} / \mathrm{ml}$ ). The injection of AAV-ChR2-virus was made through a guide cannula targeting the LA at least 2 weeks before behavioral testing (see above). Body weight and symptoms of sickness were monitored. One week before use, the mice were trained with dummy cannula removal and fiber insertion.

Optical stimulation and behavioral testing. To be tightly fixed to the guide cannula pedestal, an optical polymer fiber $(200 \mu \mathrm{m}$ of diameter, Prizmatix) was glued through an infusion cannula holder and assembled with a locking cap collar (Plastics One). The projection distance out of the guide cannula tip $(1-1.5 \mathrm{~mm})$ was set to allow positioning the fiber above the LA. One day before acquiring the associative fear, all the mice explored freely the Context A for $3 \mathrm{~min}$ and then habituated to tones. The following day, CS were delivered together with trains of blue light pulses ( $20 \mathrm{~Hz}, 30 \mathrm{~s}, 2 \mathrm{~ms}$ light pulses generated by pClamp10 software) produced by a $460 \mathrm{~nm}$ ultra high-power LED (UHP-460, Prizmatix) and terminated or not with US application (see Fig. 8). Then, mice were presented with $\mathrm{CS}^{+}$in another Context B (Recall), and the freezing response was analyzed.

\section{Statistical analysis}

Most data were analyzed using Student's $t$ tests. However, when data were not following a normal distribution, we applied the Mann-Whitney rank-based statistical test. When studying the impact of two factors (genotype and treatment) in pharmacological rescue experiments (bicuculline), we used two-way ANOVA Student-Newman-Keuls post hoc 
A

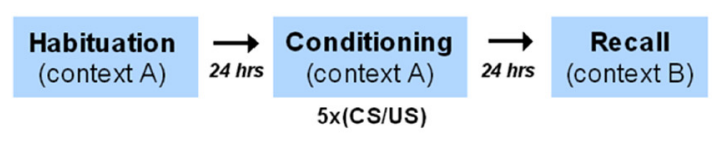

$\mathbf{B}_{1}$

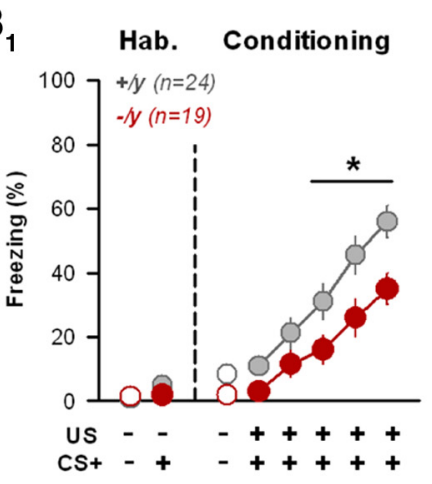

$\mathbf{D}_{1}$

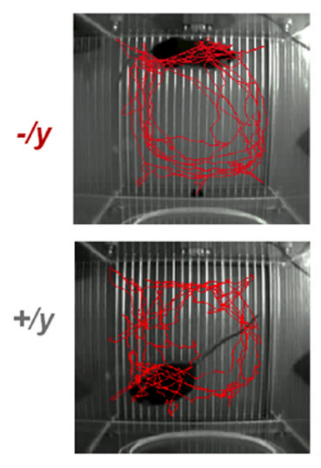

$B_{2}$

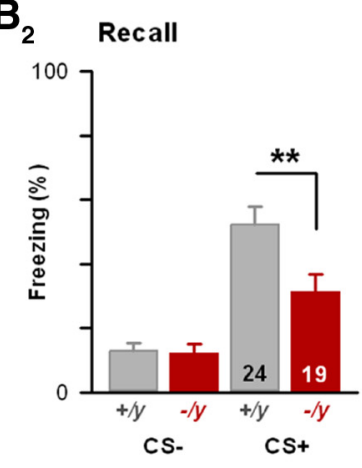

$D_{2}$
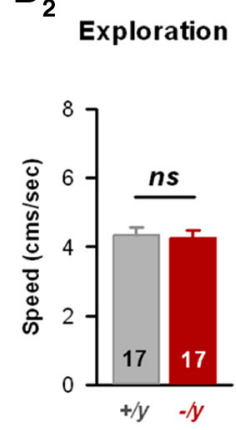

$\mathbf{C}_{1}$

$\begin{gathered}\text { Cond. } \\ \text { (context A) }\end{gathered}$
\[ 24 \text { hrs } \]$\quad \begin{gathered}\text { Recall } \\ \text { (context B) }\end{gathered}$

$\mathrm{C}_{2}$
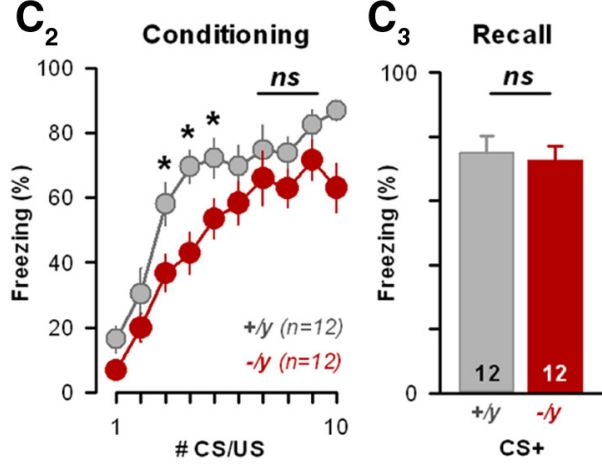

$\mathrm{E}_{2}$
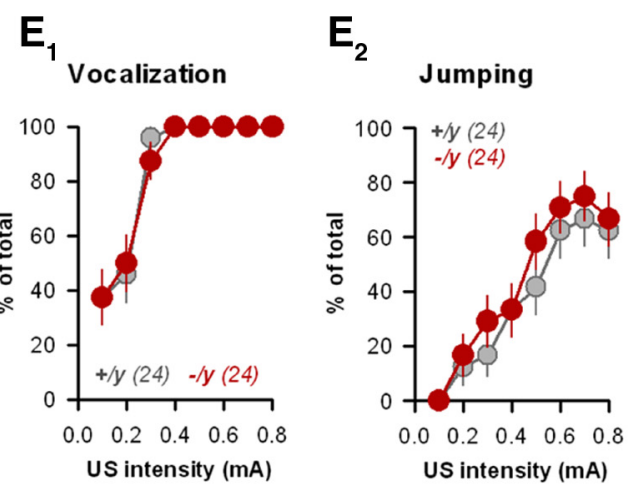

Figure 1. Deficits in cued fear learning in the absence of the ID-gene il/ rap/1.A, $\boldsymbol{C}_{1}$, Behavioral paradigms. $\boldsymbol{B}, \boldsymbol{C}$, Freezing levels observed before and during $C S / U S$ pairings $\left(\boldsymbol{B}_{1}, \boldsymbol{C}_{2}\right)$ or during the recall test $\left(\boldsymbol{B}_{2}, \boldsymbol{C}_{3}\right)$ in illrap/7 WT (+/y, gray circles/bars) or KO ( $-/ y$, red circles/bars) mice submitted to normal $(5 \times C S / U S)$ or reinforced (10 $\times$ CS/US) cued fear conditioning, respectively. The number of animals in each genotype is indicated. ${ }^{*} p<0.05 .{ }^{* *} p<0.01$. ns, Not significant. $\boldsymbol{D}$, Locomotor activity was tested in il/rapl 1 WT and K0 mice during the exploration phase (first 2 min in the Context A) before $\left(S\right.$ presentations. No difference was detected between genotypes $\left(\boldsymbol{D}_{2}\right)$. $\boldsymbol{E}$, Pain sensitivity was tested in WT and $K 0$ animals by scoring the vocalization $\left(\boldsymbol{E}_{1}\right)$ and escaping responses $\left(\boldsymbol{E}_{2}\right)$ for shocks of increasing intensities. WT and $\mathrm{KO}$ animals exhibited similar behavioral responses.

analysis to test for differences between groups of interest. Amplitude and frequency of spontaneous or miniature events were analyzed, and medians were directly compared as described above. Occasionally, cumulative distributions were compared using the nonparametric KolgomorovSmirnov test. Box plots in Figure 5 were done using SigmaPlot software (Systat Software).

\section{Reagents}

Picrotoxin was from Sigma-Aldrich, and QX-314 was from Alomone Labs. TTX was purchased from Latoxan and stock solution prepared in acetate buffer at $\mathrm{pH}$ 4.5. Bicuculline was purchased from Ascent Scientific.

\section{Results}

\section{Deficits in cued fear learning in the absence of the}

ID-gene illrapl1

Associative fear learning can easily be induced in rodents (Ledoux, 2000) and is classically monitored by measuring the degree of freezing reaction elicited upon subsequent presentations of the sole conditioning stimulus. We thus tested illrapl1-/y and $+/ y$ littermates using a discriminative, associative fear learning/recall test paradigm (Fig. 1). After habituation in Context A, animals were submitted 5 times to 2 distinct tones: the $\mathrm{CS}^{+}$tone coupled to a foot shock (US) and an uncoupled $\mathrm{CS}^{-}$tone (see Materials and Methods). The following day, in another context (Context $\mathrm{B})$, animals were submitted to a single $\mathrm{CS}^{+}$presentation (Recall, Fig. $1 A, B_{2}$ ). We first noticed that illrapl1-/y animals exhibited a significant delay in expressing the conditioned fear response to the last three CS presentations (Fig. $1 B_{1} ; p<0.05$ ). Accordingly, when tested, the recall of cued associative memory was also altered in KO mice: illrapl1-/y mice exhibited a lower fear response than their WT littermates while hearing the first CS (ill rapl1 $+/ y, 47 \pm 5 \%$; Il1 rapl1 $-/ y, 29 \pm 5 \%, p<0.01$; Fig. $1 B_{2}$ ). To test for an eventual deficit in memory retention, animals were submitted to a reinforced conditioning session (10 CS/US pairings, Fig. $1 C$ ). Interestingly, under these strong learning conditions, ill rapl1 $\mathrm{KO}$ mice did not exhibit any deficit in both the level of freezing at the last CS/US presentations $\left(\mathrm{CS} / \mathrm{US}_{7-9}, p>0.05\right)$ (Fig. $1 C_{2}$ ) and during the recall test (illrapl1 $+/ y, 75 \pm 5 \%$; illrapl1-/y, $73 \pm 5 \%, p>0.05$, Fig. $1 C_{3}$ ). This indicates that, once formed, cued fear memory is well retained, and also that the potency of learning is preserved in the absence of Il1 rapll.

To avoid confusion from potential locomotor hyperactivity, we analyzed the mean distance run by the mice during the habituation/exploration period, which did not differ between $\mathrm{KO}$ mice and their WT littermates (Fig. 1D). In addition, we challenged the mice for pain thresholds: illrapl1 $-/ y$ and $+/ y$ animals started vocalization (Fig. $1 E_{1}$ ) and escaping-jumping responses (Fig. $1 E_{2}$ ) for the same shock intensity, indicating that pain sensitivity was not altered in ill rapl1 mutant animals. Together, these results suggest that information processing within the amygdala may be impacted by ill rapl1 mutation. 
A

Thalamo-LA LTP
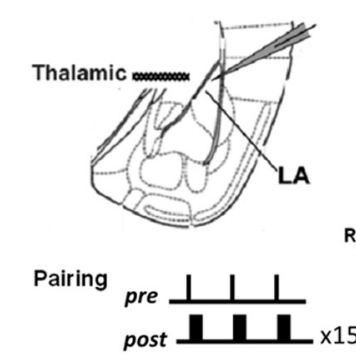

$\mathrm{C}_{1}$ ex vivo in PTX

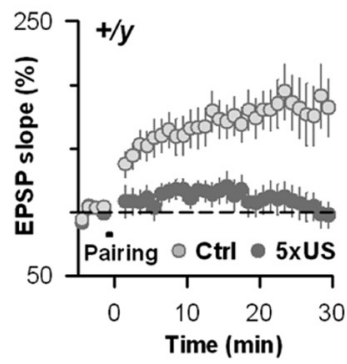

$\mathbf{B}_{1}$

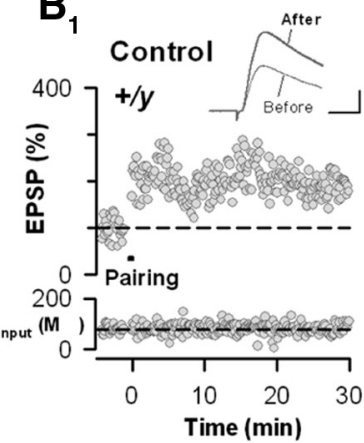

$\mathbf{C}_{2}$

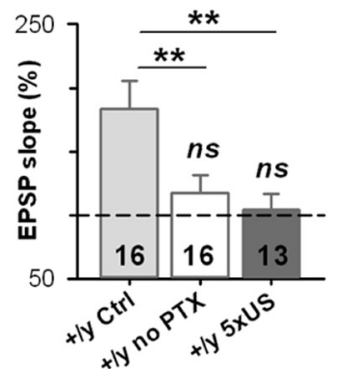

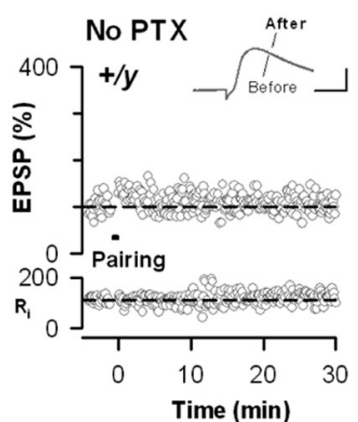

$D_{1}$ ex vivo in PTX

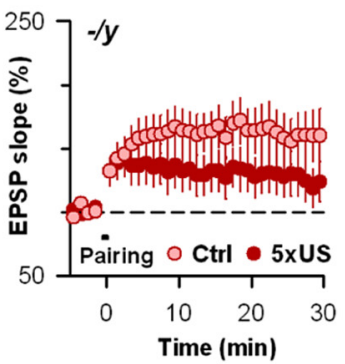

$\mathbf{B}_{1}$

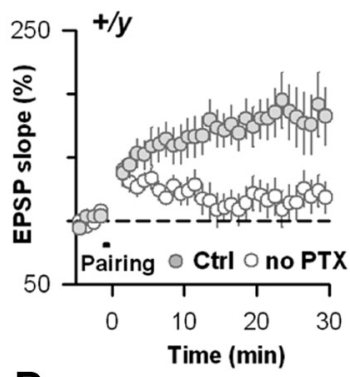

$\mathbf{D}_{2}$

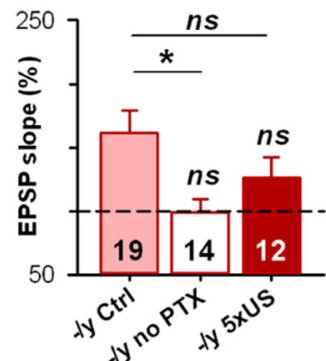

Figure 2. Constitutive il11ap/1 deletion impairs fear-learning associated LTP induction in vivo. A, Scheme of the acute slice preparation with the positioning of recording and stimulating electrodes. The pairing protocol used to induce LTP is indicated. $\boldsymbol{B}_{1}$, Typical time course of EPSP slope in WT animals after associative STDP-pairing application in control and no PTX conditions. Insets, Typical EPSPs. Calibration: $4 \mathrm{mV}, 5 \mathrm{~ms}$. $\boldsymbol{B}_{2}$, Average time courses in both conditions in WT mice. $\boldsymbol{C}$, Fear learning mediates thalamo-LA LTP occlusion in il1rapl1+/y mice. $\boldsymbol{C}_{1}$, Time course of thalamo-LA EPSP slope before and after pairing in il1rapl1 + /y naive (Ctrl) and conditioned ( $5 \times$ US) adult mice. $C_{2}$, Mean LTP in naive illrap/1+/y in both control and no PTX conditions, and fear-conditioned il1rap $17+/ y$ adult mice. ${ }^{* *} p<0.01$. D, Fear learning did not induce complete thalamo-LA LTP occlusion in il1rapl1 - /y mice. $D_{1}$, Time course of thalamo-LA EPSP slope before and after pairing in il1rap/1 - /y naive (Ctrl) and conditioned ( $5 \times$ US) adult mice. $D_{2}$, Mean LTP in naive il/rap/1 - /y in both control and no PTX conditions, and fear-conditioned /l1 rap/1 - /y adult mice. ${ }^{*} p<0.05$.

\section{Constitutive ill rapl1 deletion impairs fear associated LTP induction in vivo}

Associative long-term synaptic plasticity at thalamo-LA synapses underlies the acquisition of fear conditioning (Rumpel et al., 2005; Humeau et al., 2007). Thus, the behavioral deficits observed in illrapl1-deficient mice within the acquisition session must be linked to a decrease in the gating of amygdala associative synaptic plasticity. We therefore examined the induction of associative, postsynaptic LTP at thalamo-LA synapses illrapl1 KO and WT in acute brain slices (Fig. 2). At adult synapses, as in juveniles (Bissière et al., 2003), a robust LTP can be triggered by coincident bursts of preactivites and postactivities, but only in the presence of the GABAA-R antagonist PTX (100 $\mu \mathrm{M})$ (Fig. 2B). Interestingly, when tested in these standard conditions, both ill rapl1 WT and KO animals exhibited similar levels of LTP (il1 rapl1 $+/ y, 183 \pm 23 \%$; ill rapl1 $-/ y, 161 \pm 18 \%, p>0.05$; Fig. $2 C, D$ ), indicating that ill rapll deletion did not alter the capability of thalamo-LA synapses to produce postsynaptic LTP.

Noteworthy, these experiments were conducted in the absence of ionotropic GABAergic transmission, therefore bypassing an eventual GABAergic modulation. Thus, to examine the occurrence of genuine thalamo-LA LTP in vivo during associative fear learning, we tested LTP levels in slices from fear-conditioned KO and WT animals. Indeed, it was previously reported that fear conditioning led to occlusion of thalamo-LA LTP in brain slices (Hong et al., 2011). ill rapl1- $/ y$ and $+/ y$ animals were first submitted to the associative fear conditioning described above (5 $\mathrm{CS} / \mathrm{US}$ ), and brain slices were prepared $24 \mathrm{~h}$ after the last CS/US presentation. Compatible with an effect of fear conditioning in both genotypes, LTP levels in conditioned animals were nonsignificant ( $p>0.05$ compared with baseline; Fig. $2 C, D$ ). However, while in conditioned WT mice, a pronounced occlusion of LTP was observed (illrapl1+/y $\mathrm{LTP}_{\text {naive }}, 183 \pm 23 \%$ LTP $_{5 \mathrm{CS} / \mathrm{US}}$, $104 \pm 12 \%, p<0.01$ ) (Fig. 2C), LTPs obtained in naive and conditioned illrapl1 KO slices were not significantly different (illrapl1-/y $\mathrm{LTP}_{\text {naive }}, 161 \pm 18 \%$ LTP $_{5 \mathrm{CS} / \mathrm{US}}, 126 \pm 16 \%, p>$ $0.05)$. This indicates that fear-induced LTP occlusion is only partial in ill rapll $\mathrm{KO}$ mice, probably because of a lower LTP induction in vivo during fear acquisition. We propose that this impairment of LTP induction could, at least partially, contribute for both the delay in fear acquisition and the deficit in the recall of cued fear memory observed in ill rapl1-deficient animals.

Increased I/E balance in LA principal cells is associated with il1rapl1 mutation

Gating of AMPAR-mediated, NMDAR-dependent postsynaptic LTP requires the relief of the magnesium block of NMDA receptors through the firing of postsynaptic cells. Previous studies demonstrated the crucial role of local GABAergic interneurons in controlling the postsynaptic discharge (Pouille and Scanziani, 2001; Gabernet et al., 2005), thereby limiting the gating of synaptic plasticity through postsynaptic hyperpolarization (Bissière et al., 2003). Thus, we examined feedforward inhibition (FFI) in the LA of ill rapl1 KO and WT mice after activation of major excitatory inputs (Fig. 3). To achieve that, LA principal cells were recorded at two different membrane potentials, -70 and $0 \mathrm{mV}$ in physiological chloride, while stimulating thalamic excitatory fibers (Humeau et al., 2005; Gambino et al., 2010) (Fig. 3A). Through this electrophysiological manipulation of the membrane potential, we could isolate AMPAR-mediated excitation (EPSCs, at $-70 \mathrm{mV}$ ) and GABAA-R-mediated inhibition (IPSCs, at $0 \mathrm{mV}$ ) based on their different reversal potential (Fig. $3 A_{2}$ ). 

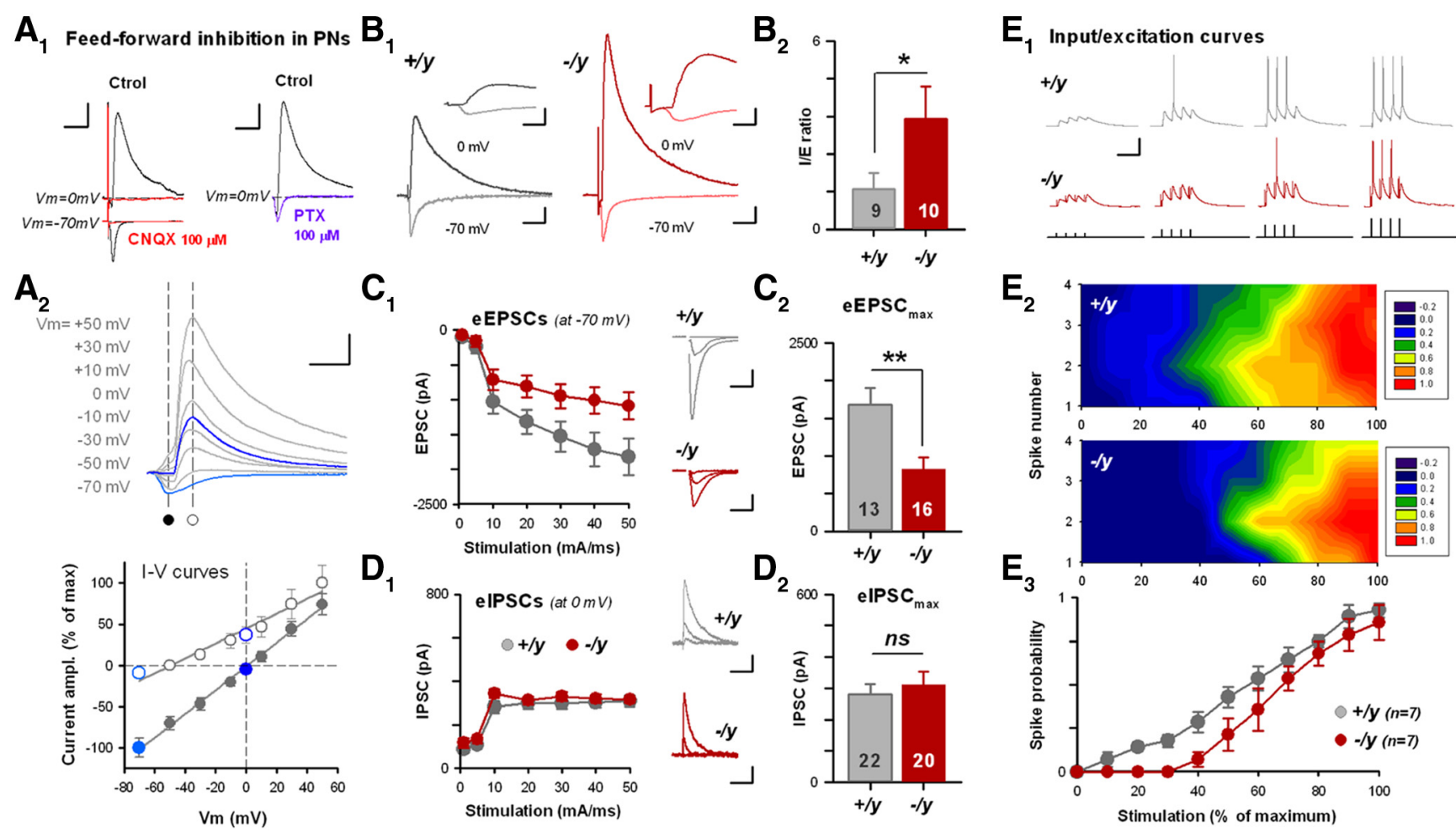

Figure 3. Increased I/E balance and lack of activation in LA principal cells are associated with illrap/1 mutation. $\boldsymbol{A}$, FFI measurements in LA principal cells. $\boldsymbol{A}_{\boldsymbol{1}}$, Pharmacological controls demonstrating that FFl is induced after thalamic fiber stimulations. $A_{2}$, AMPAR and GABAA-R-mediated PSCs can be isolated by their differential reversal potential. $\boldsymbol{B}$, FFl is increased in il1 rapl1 $\mathrm{KO}$ mice (red traces). $\boldsymbol{B}_{1}$, Typical FFI recordings using similar EPSC values. Calibration: top, $150 \mathrm{pA}, 5 \mathrm{~ms}$; bottom, $50 \mathrm{pA}, 20 \mathrm{~ms}$. $\boldsymbol{B}_{2}$, Mean I/E ratio obtained at thalamo-LA synapses in $+/ y$ and $-/ y$

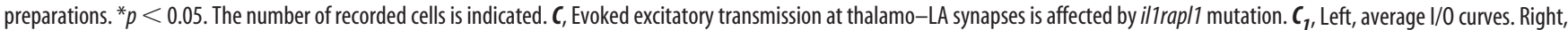
Typical EPSCs recorded for $0.1,1$, and $10 \mathrm{~mA}$ stimulations in $+/ y$ and $-/ y$ preparations. Number of recorded cells is indicated. Calibration: $200 \mathrm{pA}, 30 \mathrm{~ms}$. $C_{2}$, Mean EPSC amplitude for $10 \mathrm{~mA}$ stimulations. ${ }^{* *} p<0.01$. D, Same presentation as in C but describing thalamic-evoked IPSCs. Calibration: 100 pA, $60 \mathrm{~ms}$. ns, Not significant. E, Activation of LA principal cells by incoming thalamic excitation is decreased in il/rap/1-deficient mice. $\boldsymbol{E}_{1}$, Typical recordings of LA-PNs $\mathrm{V}_{\mathrm{m}}$ upon thalamic fiber stimulations of increasing intensity in $+/ y$ and $-/ y$ preparations. Calibration: $20 \mathrm{mV}$, 40 $\mathrm{ms} . \boldsymbol{E}_{2}$, Probability map of spike occurrence at each stimulation time point $(1,2,3$, or 4$)$ and for each stimulation intensity $(0-100 \%)$. Seven and seven cells were recorded in each genotype. $\boldsymbol{E}_{3}$, Spike probability curve showing that LA cells are less efficiently activated by thalamic input in il1rap/1-deficient mice.

Accordingly, inward currents recorded at $-70 \mathrm{mV}$ were completely blocked by the AMPAR antagonist CNQX (100 $\mu$ m; Fig. $3 A_{1}$, left), whereas the outward current recorded at $0 \mathrm{mV}$ was sensitive to the GABAA-R antagonist picrotoxin $(100 \mu \mathrm{M}$; Fig. $3 A_{1}$, right). Moreover, this last component was also sensitive to AMPAR blockade (Fig. $3 A_{1}$, left, at $0 \mathrm{mV}$ ), indicating the recruitment of local interneurons as a feedforward circuit (FFI). Importantly, I/V curves recorded in WT and KO preparations were similar and could be greatly approximated by a linear fit, indicating their correct measurements (data not shown).

To directly compare FFI in WT and KO preparations, we first elicited thalamo-LA EPSCs of comparable size in LA principal cells (at $-70 \mathrm{mV}, 130-60 \mathrm{pA}, p>0.05$ between both groups) and compared the amplitude of the outward inhibitory current recorded at $0 \mathrm{mV}$ (Fig. 3B). Strikingly, IPSCs were found to be significantly higher in KO preparations (Fig. $3 B_{1}$ ), and the I/E ratio was exacerbated in ill rapll mutant mice (Fig. $3 B_{2}$ ). Theoretically, the increase of $\mathrm{I} / \mathrm{E}$ balance (calculated here as a ratio) in ill rapl1 KOs could result from an increase in inhibitory, or a decrease in the excitatory, transmission onto LA principal cells. To refine our observation, we compared eEPSC and eIPSC amplitudes for increasing stimulation intensities (Fig. 3C,D). As shown in Figure 3C, input/output (I/O) relationships of thalamo-LA eEPSCs were clearly impacted by ill rapll mutation $\left(\mathrm{eEPSC}_{\max }, p<0.01\right)$. Thus, recurrent to some observations in pyramidal cells in hippocampus (Pavlowsky et al., 2010), the absence of Il1rapl1 led to a reduction of glutamatergic transmission in pyramidal cells. In stark contrast, inhibitory I/O curve was not modified by the mutation (Fig. $3 D$ ), indicating that the observed change in the $\mathrm{I} / \mathrm{E}$ ratios (Fig. $3 \mathrm{~B}$ ) can be mostly attributed to a decrease in the excitatory component.

To assess for the functional consequences of these synaptic defects on amygdala output, we tested the ability of thalamic inputs to elicit spike discharges in LA principal neurons (Fig. 3E). Bursts of 4 presynaptic stimulations (at $20 \mathrm{~Hz}$ ) were applied at various intensities and eventual postsynaptic spikes counted. Noteworthy, in KO preparations, the first generated spikes occur for greater stimulation intensities than in WT preparations (Fig. $3 E$ ), suggesting that ill rapll mutation lowers LA-PN activation by incoming thalamic synaptic inputs.

\section{Impact of illrapl1 deletion onto excitatory synaptic inputs to} LA interneurons

Local interneurons of the LA account for $\sim 20 \%$ of cell bodies (McDonald, 1982), tightly regulating principal cell excitability by providing strong feedforward inhibition (Szinyei et al., 2000; Chu et al., 2012). Moreover, accumulating evidence points for a role of GABAergic transmission in regulating fear conditioning (Ehrlich et al., 2009). To answer whether ill rapll mutation had a specific impact on excitatory level reaching interneurons, we crossed ill rapl1 mutant mice with GAD67-eGFP transgenic mice (Tamamaki et al., 2003), making it easy to visualize interneurons with fluorescence (Fig. $4 A_{1}$ ). Interneurons, although highly variable in their electrophysiological parameters and expression of specific 
A 1 GAD67-eGFP/IIrapl1 mice

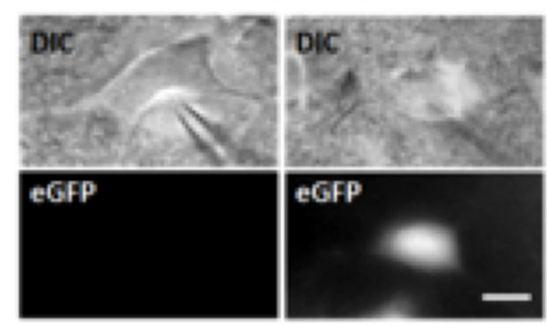

B

LA-INs discharge
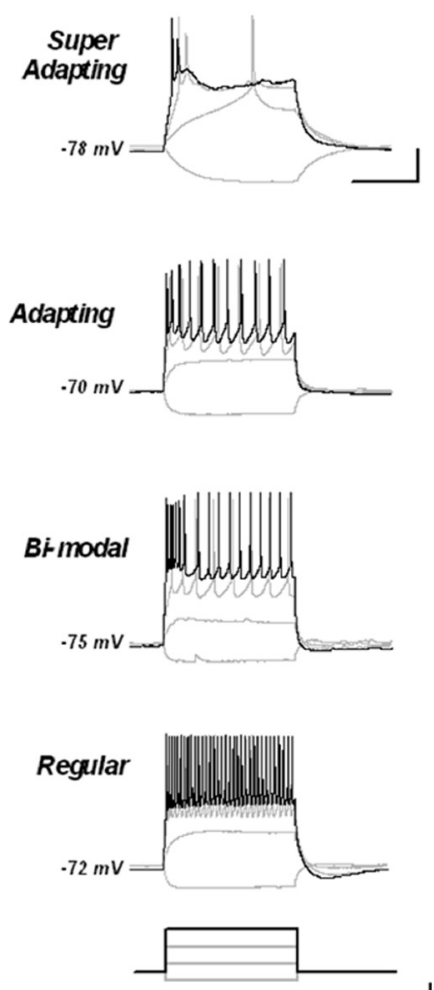

$B_{2}$ Spiking patterns

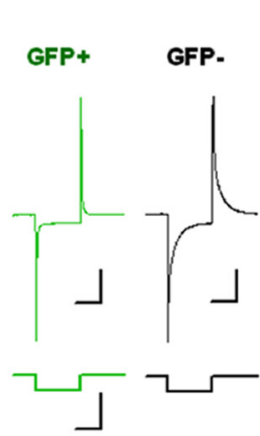

$\mathrm{C}_{1}$
$\mathrm{A}_{2} \quad$ LA-INs recordings

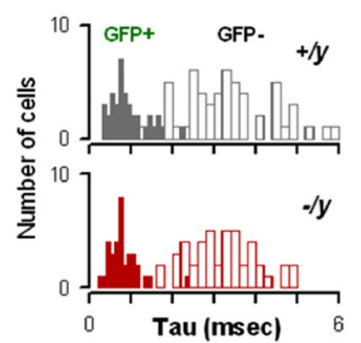

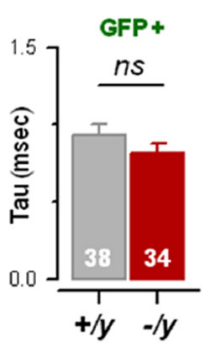

$\mathrm{C}_{2}$
Evoked EPSCs
2

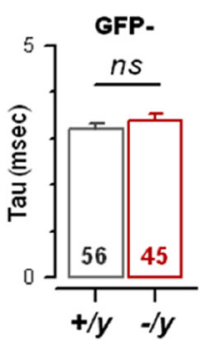

$E P S C_{\text {max }}$
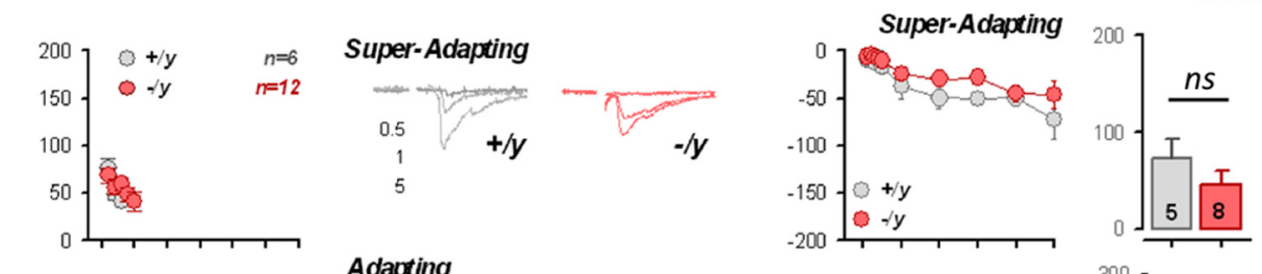

\section{Adapting}
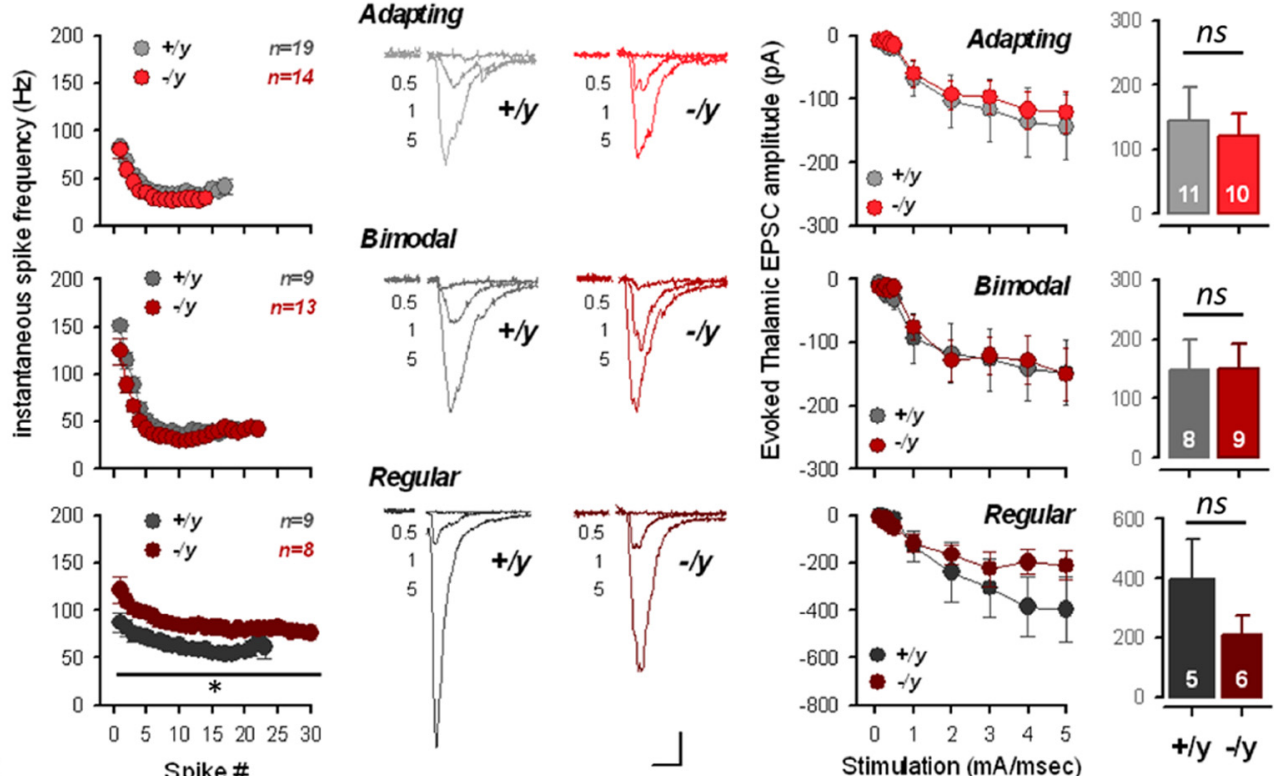
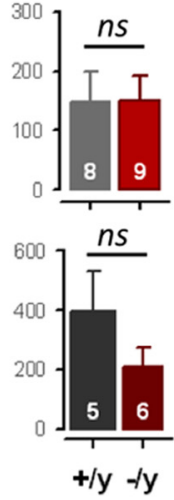

Figure 4. Excitatory transmission onto amygdala interneurons is preserved in il/ rap/1-deficient mice. A, Amygdalar GABAergic neurons were directly visualized and recorded by GFP fluorescence after crossing i/1 rap/1 mutant mice with GAD67-eGFP mice (see Materials and Methods). $\boldsymbol{A}_{1}$, Principal cells can be separated from interneurons by looking at cellular capacitance during the seal test. $\boldsymbol{A}_{\mathbf{2}}$, Density and capacitance of GABA-ergic (GFP ${ }^{+}$) and principal (GFP ${ }^{-}$) cells in Il1 rapl1 WT and K0 preparations. Number of recorded cells is indicated. $\boldsymbol{B}$, Spiking patterns of LA interneurons. $\boldsymbol{B}_{\boldsymbol{1}}$, LA interneurons were classified in four subclasses based on spiking behavior (for a detailed description of interneuron classification, see Materials and Methods). $\boldsymbol{B}_{\mathbf{2}}$, Mean spiking frequency against spike number for each subclass of interneuron. $\boldsymbol{C}$, Excitatory evoked transmission of LA interneurons after thalamic stimulation. $\boldsymbol{C}_{1}$, Mean EPSC amplitude for 0.5 , 1 , and 5 mA stimulations in WT and KO interneurons. Calibration: 100 pA, 20 ms. $C_{2}$, Left, I/0 curves of LA interneurons for a 5 mA stimulation in WT and K0 interneurons. Right, Mean EPSC amplitude at 5 mA stimulation intensity for all LA interneurons. Number of recorded cells is indicated.

biological markers (Spampanato et al., 2011), could be distinguished from principal cells by cellular capacitance. Indeed, measurement of the exponential $\tau$ of the cellular response to a -10 $\mathrm{mV}$ voltage jump revealed a clear segregation with principal cells, a parameter that was not itself modified by Il1 rapl1 mutation for both cell populations (Fig. $4 A_{2}$ ). Interneurons were classified in different subclasses based on a previous study looking at diverse electrophysiological parameters of LA interneurons (Sosulina et al., 2010). Indeed, mRNA expression of different calcium binding proteins and neuropeptides was not very conclusive to further classify these populations (Sosulina et al., 2006). Thus, interneurons were assigned to a specific population looking solely at electrophysiological parameters (see Materials and Methods). To that end, we performed whole-cell patch-clamp recordings in current-clamp mode from GFP-expressing LA cells in il1rapl1 $\mathrm{KO}$ and WT mice (Fig. 4B,C). Combined analysis of spiking pattern and other electrophysiological parameters allowed us to separate interneurons into four classes (Fig. $4 B_{1}$ ). Superadapting neurons showed a few spikes in the beginning of the depolarizing pulse before exhibiting spike failure/adaptation. Adapting neurons were characterized by a strong adaptation of spiking pattern during the depolarizing current step. Bimodal neurons, on the other hand, started spiking in a burst-fashion manner before adapting their firing pattern. Finally, regular spiking neurons were characterized by very low spike adaptation (Fig. $4 B_{1}$ ). Apart from superadapting neurons, all our subclasses share common 
A Dendritic spine morphology on LA principal cells

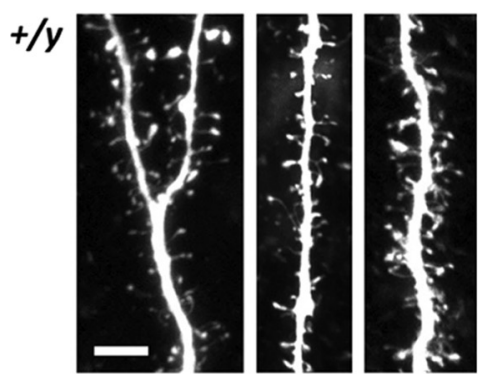

$\mathrm{A}_{2}$

2 Spine density

$A_{3}$ spine morphology
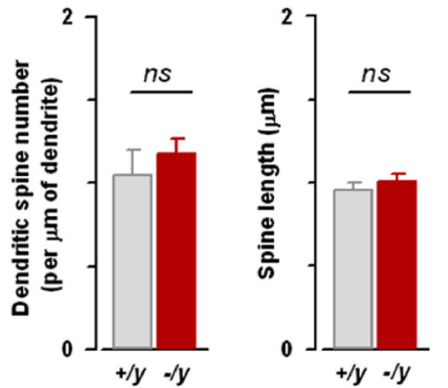

$\mathrm{C}_{1}$ miniature EPSCS
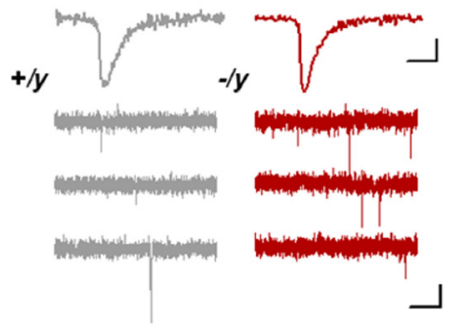
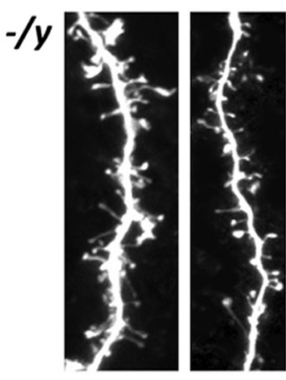

$\mathrm{A}_{4}$
$B_{1}$ All synapses

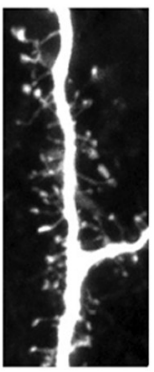

Spine distribution
PSD95

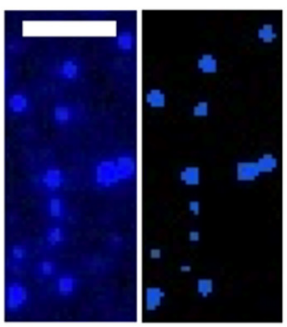

$\mathrm{B}_{2}$
$D_{1}$ Thalamo-LA

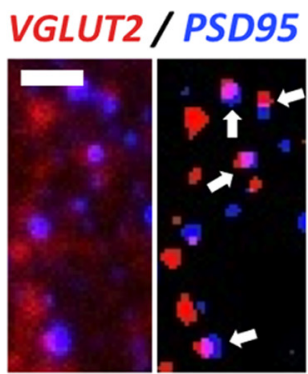

D

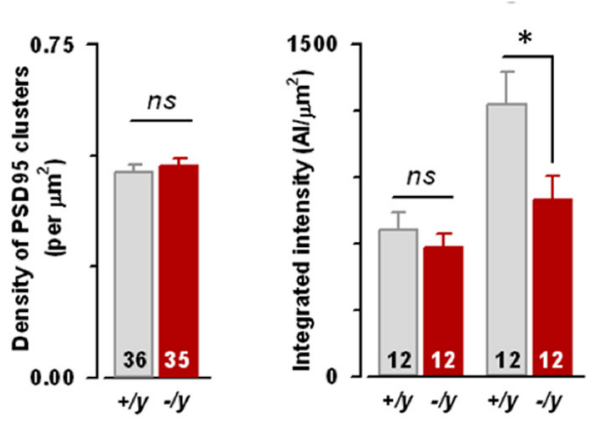

E

$\mathbf{C}_{2}$ Frequency

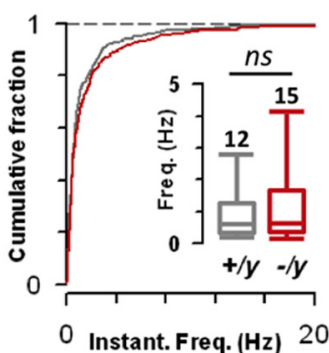

3 Amplitude

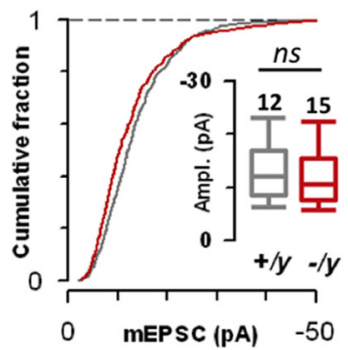

Paired-pulse stimulations

Figure 5. Morphology of $L A$ excitatory synapses in constitutive il1rap/1 mutant mice. $\boldsymbol{A}$, Morphology of $L A$ principal cell dendrites is preserved in il1rap/1-deficient mice. $\boldsymbol{A}_{1}$, Portions of neurobiotin-filled LA principal cell dendrites were analyzed and compared between genotypes. $\boldsymbol{A}_{2-4}$, Analysis of spine density, morphology, and distribution of different spine types. $\boldsymbol{B}$, Morphological examination of LA synaptic contacts. $\boldsymbol{B}_{1}$, Typical immunolabeling against PSD95. $\boldsymbol{B}_{2}$, Density of PSD95 clusters for both genotypes. $\boldsymbol{C}$, Miniature EPSC recordings on LA principal cells for both genotypes. $\boldsymbol{C}_{1}$, Representative trace of mEPSC recordings in both genotypes. $\boldsymbol{C}_{2-3}$, Cumulative distribution of mEPSC frequency and amplitude for both genotypes. Insets, Medians of frequency and amplitude, respectively. D, Putative synapses were identified as closely apposed VGLUT2/PSD95 clusters (see Materials and Methods). Scale bars, $2 \mu \mathrm{m}$. $\boldsymbol{D}_{\boldsymbol{1}}$, Typical immunolabeling showing apposed PSD95/NGLUT2 clusters. $\boldsymbol{D}_{2}$, Integrated intensity of PSD95 and VGLUT2 in apposed clusters for both genotypes. ${ }^{*} p<0.05$. E, Paired pulse recordings for both genotypes. PPR was calculated as the ratio of the second response to the first one.

electrophysiological parameters with previously defined subtypes of LA interneurons (Sosulina et al., 2010). In both genotypes, plotting spiking frequency against spike number showed clear differences in the spiking behavior of these different populations (Fig. $4 B_{2}$ ); no differences were observed between genotypes, except for regular spiking neurons, which display a higher frequency in $\mathrm{KO}$ animals $(p<0.05)$. Next, we assessed excitatory signals reaching those categories by constructing I/O curves after thalamic stimulation (Fig. 4C). In stark contrast with the situation found in LA principal cells, none of the interneuron groups displayed significantly different I/O curves between WT and $\mathrm{KO}$ preparations (Fig. 4C). Noteworthy, superadapting and regularspiking neurons exhibited a tendency to a decrease of thalamic EPSCs, which remained nonsignificant $(p=0.093$ and $p=0.217$, respectively). We raise two major conclusions from these genetically driven recordings: (1) the lack of impact of ill rapll mutation onto excitatory transmission in LA interneurons may largely contribute to the increase of FFI described above (Fig. 3); and (2)
Il1 rapl1 may play a functional role in the postsynaptic compartment, as LA recordings involving the same presynaptic but different postsynaptic compartments exhibited or not a functional impact of the mutation (see also Discussion).

Morphological and functional characterization of excitatory synaptic inputs to LA principal neurons in il1 rapl1 WT and KO mice

We next performed morphological analysis of dendritic spines from LA principal cells to determine whether Il1rapl1 plays a role in synapse formation and/or maturation in the amygdala (Fig. 5). We filled LA principal cells with neurobiotin during whole-cell patch-clamp recordings and thoroughly analyzed dendritic spine density and morphology after fixation (see Materials and Methods) (Fig. 5A). Using this method, we could not find any differences between genotypes (Fig. $5 A$ ), which was in good line with two other observations. First, global analysis of PSD95 cluster density using immunocytochemistry did not allow separating 
WT and KO preparations (Fig. 5B). Furthermore, no impact of the mutation on mEPSC frequency or amplitude recorded in LA principal cells could be detected (Fig. 5C), thus suggesting that the amygdala neuropile was not strongly affected by the removal of Illrapl1.

Then, taking benefit of differential VGLUT1/VGLUT2 expression in amygdala-projecting brain structures (Fremeau et al., 2001), we specifically examined the morphology of thalamo-LA (expressing VGLUT2) synapses by analyzing the intensity of apposed VGLUT2/PSD95 clusters (Fig. 5D) (see Materials and Methods). Strikingly, in PSD95/VGLUT2 appositions, the VGLUT2 levels were significantly lower in illrapl1 $\mathrm{KO}$ mice ( $-35 \%$ of integrated intensity; Fig. $5 D_{2}$, bottom, $p<0.05$ ), whereas PSD95 clusters were unaffected (Fig. $5 D_{2}$ ). As these results point to an impact of the mutation at the presynaptic level, we compared paired pulse recordings at thalamo-LA synapses but failed to detect changes in presynaptic release probability (Fig. 5E). Thus, our data suggest that Il1 rapl1 controls both functional and morphological parameters at thalamo-LA excitatory synapses.

\section{Ubiquitous distribution of ill rapl1 mRNA in neuronal populations of amygdala}

To get some insights on the rationale to ill rapl1 - /y induced I/E imbalance, we then set out to examine the distribution of ill rapl1 mRNA in the brain. Previous work raised some evidence for ill rapll expression in olfactory bulb, hippocampus, and cortex (Carrié et al., 1999). However, no robust and detailed demonstration of ill rapl1 expression pattern has yet been published. We thus performed in situ hybridization of illrapl1, together with vglut1 and gad67, to allow for the comparison of its relative expression in inhibitory and excitatory brain regions. Indeed, vglut 1 labels the major glutamatergic population of cells in the cortical forebrain regions (Fig. 6A, C), whereas gad67 labels all GABAergic neurons in the brain (Fig. $6 A, B$ ). Slides were first exposed to phosphor imager screen (Fig. $6 A$ ), and then the cellular resolution was obtained through dipping into photographic emulsion combined with toluidine blue counter staining (see Materials and Methods). illrapll was probed using 7 oligonucleotides spread over the different exons of the gene. All probes provided the same profile of expression. As expected, probe number 6 (data not shown) and 7 raised within the deleted exon 5 provided no signal when incubated over illrapll - /y slices (Fig. 6A). Overall, ill rapl1 expression was very low compared with that of vglut 1 or gad67. Higher expression levels were recurrently seen in olfactory bulbs (data not shown) and in dentate gyrus of the hippocampus (Fig. 6A). In the amygdaloid complex, expression spans all excitatory (basolateral amygdala) and inhibitory (intercalated cells and central amygdala) regions homogeneously. Regional observations were confirmed by the investigations on slides at the cellular levels (for better visualization, silver dots were converted to red in Fig. $6 B-D)$. Although GABAergic and glutamatergic territories are well delineated in Figure $6 B, C$, ill rapl1 specific pattern appeared homogeneously distributed ruling out the possibility for a selective lack of expression in one or the other subclass of neurons (see quantifications in Fig. $6 B-D$ ). However, a specific lack of expression in a subclass of interneurons cannot be ruled out.

\section{Cued fear learning is rescued by preconditioning infusion of GABAA-R blockers in the LA of il1 rapl1-deficient mice}

Yet, a scenario emerges in which ill rapl1 $\mathrm{KO}$ mice's impairment in associative learning is the result of exacerbated I/E balance in the LA during CS/US association. Ex vivo experiments suggest that this could in turn lead to lower LTP induction in ill rapl1 $\mathrm{KO}$ animals. The next series of experiments aimed at normalizing behavior in $\mathrm{KO}$ mice by restoring $\mathrm{I} / \mathrm{E}$ balance before learning. In this line, previous studies used local or systemic treatment increasing GABAergic transmission to interfere with the acquisition or expression of the conditioned fear response (Sanger and Joly, 1985).

We thus depressed intra-LA GABAA-R-mediated inhibition during the CS/US association (Fig. 7) by infusing the specific antagonist bicuculline into the LA of il1rapl1- $/ y$ and $+/ y$ littermates before conditioning (Fig. 7). To that end, mice were chronically implanted above the LA (guide cannula positions in Fig. $7 B$ ), and local infusion of bicuculline was performed bilaterally 30-60 min before the fear conditioning session (see Materials and Methods). Importantly, first attempts using doses previously used in rats (50 $\mathrm{ng} / 200 \mathrm{nl}$ per side) were readily leading to epileptic seizures immediately after infusion (Berlau and McGaugh, 2006). We thus lowered the dose to $20 \mathrm{ng} / 200 \mathrm{nl}$ and retained only the animals in which the guide cannula tips were immediately above the LA to avoid unspecific effects (Fig. 7B). With these safeguards, no obvious seizures were observed during the drug treatment, although we noticed a slight effect of drug treatment on animal locomotor activity (ANOVA, $F_{(1,53)}=8,115 ; p=$ 0.006) (Fig. 7C). However, there was no difference in general locomotion between WT and KO-treated animals (SNK post hoc, $p=0.706$ ), thus allowing comparing the behavioral consequences of the treatment in both genotypes. We then compared the freezing levels obtained during and $24 \mathrm{~h}$ after the fear conditioning session and compared with nonimplanted mice (Fig. $7 \mathrm{D}, E)$. Although we present the whole acquisition curve, bicuculline treatment did not reach significance until the fifth CS presentation, and comparisons between groups were done at this time point. Two-way ANOVA revealed an interaction effect between genotype and treatment (ANOVA, $F_{(1,57)}=5,043 ; p=$ 0.029). In control animals, as shown before, the fear response exhibited by $\mathrm{KO}$ mice at the fifth CS/US presentation during the conditioning session was lower than their WT littermates (SNK post hoc, $p=0.011$ ) (Figs. $1 A, 7 D)$. Strikingly, in bicucullinetreated animals, freezing levels at the fifth CS/US presentation were found indistinguishable between genotypes (SNK post hoc, $p=0.399)$, and a significant effect of the treatment was found in KO (SNK post hoc, $p=0.002$ ) but not WT animals (SNK post hoc, $p=0.850)$. When looking at freezing levels during recall, we noticed a significant interaction between genotype and drug treatment (ANOVA, $F_{(1,57)}=4,820 ; p=0.032$ ), leading to a normalization of the freezing deficit (control, SNK post hoc, $p=$ 0.008 ; treated, SNK post hoc, $p=0.479$; Fig. $7 E$ ). Normalization of acquisition only became significant at the fifth CS presentation, probably because of incomplete blockade of inhibitory system or a lack of excitation by incoming inputs at initial CS/US associations. However, together, these observations convincingly show a normalization of cued fear acquisition and recall after in vivo pharmacological manipulations of the LA ionotropic GABAergic system at the time of CS/US association.

Accordingly, bicuculline treatment in conditioned illrapl1 $-/ y$ mice also restored thalamo-LA LTP occlusion (ill rapl1- $/ y$ : $\mathrm{LTP}_{\text {naive }}, 161 \pm 18 \%, \mathrm{LTP}_{5 \mathrm{CS} / \mathrm{Us}+\text { bicu }}, 88 \pm 8 \%, p<0.05 ;$ Fig. $\left.7 F\right)$. These results indicate that restoring I/E balance before learning may suffice to allow LTP induction in vivo in il1 rapl1 $\mathrm{KO}$ animals. We thus propose the existence of a causal link between the deficit in associative learning, the failure of LTP induction, and I/E imbalance within the lateral amygdala. 
A
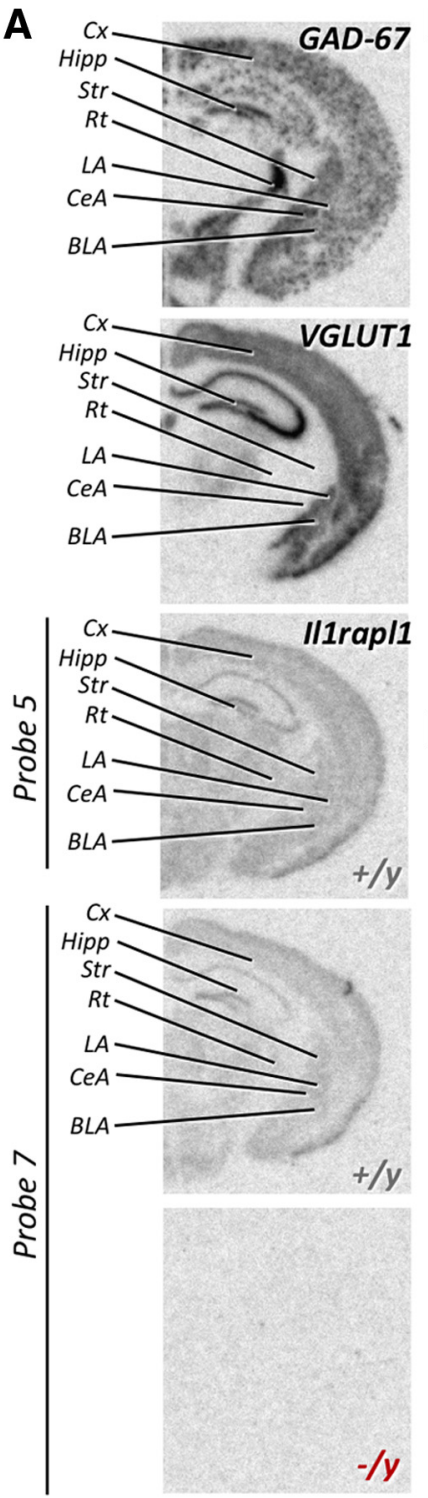

B
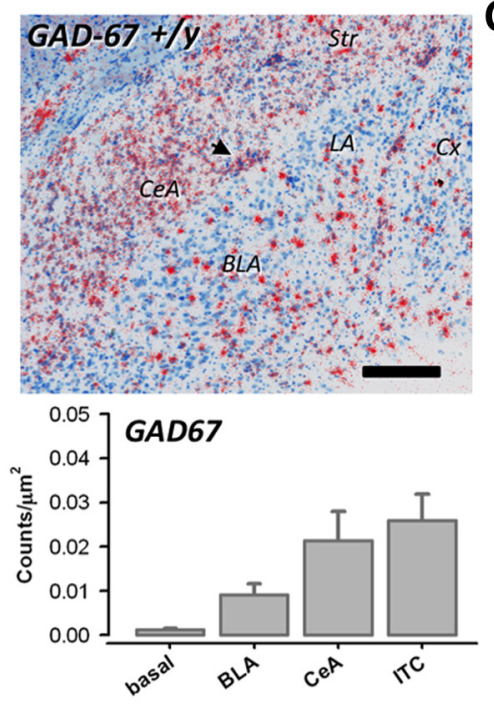

D
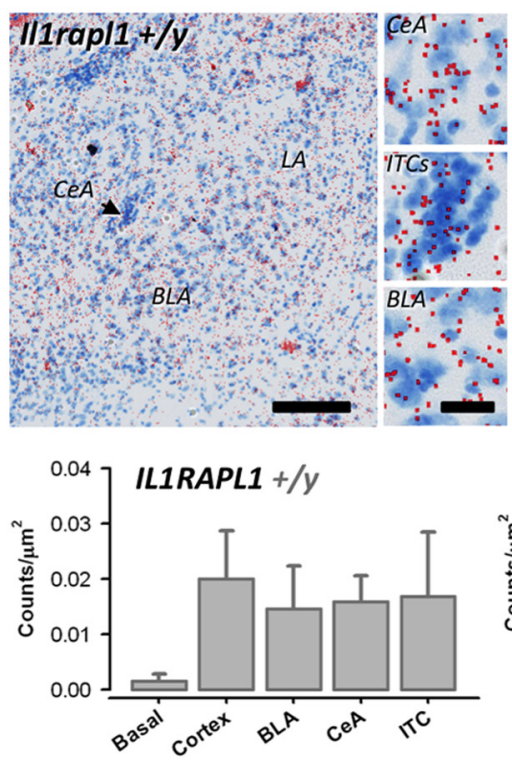
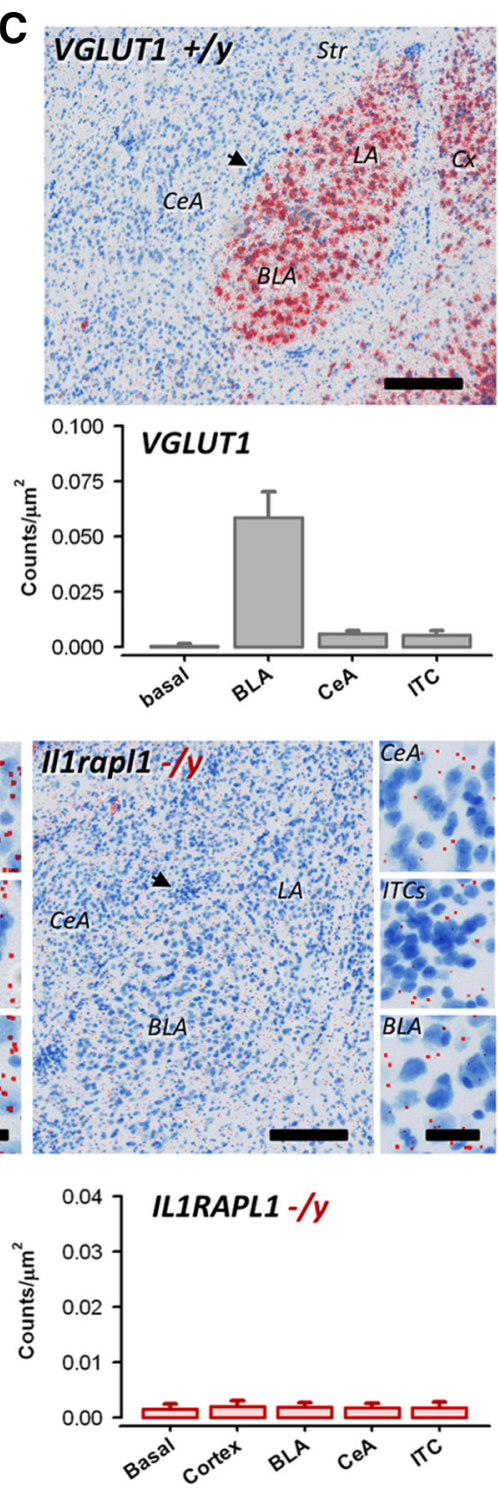

Figure 6. Ubiquitous distribution of il $1 \mathrm{rap} / 1 \mathrm{mRNA}$ in amygdala neurons. $\boldsymbol{A}$, Regional distribution of gad67, vglut1, and il1 rap/1. il1 rap/1 was probed with 7 oligonucleotides; here probe 5 and 7 are shown. Probe 7 is specific of the exon 5, deleted in the knockout model. There is absence of signal when probe 7 is incubated on $-/ y$ slices. $\boldsymbol{B}-\boldsymbol{D}$, Emulsion dipping of slices from $\boldsymbol{A}$. Silver dots were systematically masked and converted to red for display purpose. $\boldsymbol{B}$, Cellular distribution of gad67 mRNA in the amygdala. There is dense labeling in the central nucleus, whereas sparse interneurons are depicted in the basolateral divisions. $C$, Cellular distribution of vglut $1 \mathrm{mRNA}$ in the amygdala. There is dense labeling of neurons in the basolateral division, whereas the central nucleus is devoid of labeling. D. Cellular distribution of il1 rap/1 mRNA in the amygdala. Lower expression levels are detected compared with gad67 and vglut1, but - /y slices display much lower background signals (right panels). il1rapl1 expression covers all divisions of amygdala. Arrows point to ITCs. Scale bars: $250 \mu \mathrm{m}$; insets, $30 \mu \mathrm{m}$. Cx, Cortex; hipp, hippocampus; Str, striatum; Rt, reticular nucleus of the thalamus; LA, lateral amygdala; CeA, central amygdala; BLA, basolateral amygdala; ITC, intercalated cells.

\section{Direct optical activation of LA cells during acquisition of associative cued fear normalizes fear learning in il1 rapl1- deficient mice}

During associative fear learning, US is thought to act as a detonator inducing depolarization and firing of LA principal cells, instructing plasticity at synapses conveying the CS onto the same cells (Rosenkranz and Grace, 2002; Maren, 2005). This phenomenon was spectacularly demonstrated recently by Johansen et al. (2010): by pairing auditory CS with optical activation of LA principal cells, they showed that direct activation of LA principal cells was sufficient to drive cued associative fear conditioning. We implemented a similar strategy to bypass an eventual fading of the US "detonation" in ill rapl1-deficient mice (Fig. 8). To this aim, LA cells were transfected with AAV2/9.CAG.ChR2Venus.W.SV40-p1468 (U-Penn vector core) introduced through chronically implanted cannula, which also permitted the delivery of timely controlled light pulses within the LA via an optical fiber (see Materials and Methods) (Fig. $8 B-G$ ).

First, to control for the efficacy of the opsin strategy, we tested the light activation of LA principal neurons in vitro (Fig. $8 A$ ). In all transfected neurons, we observed that continuous $1 \mathrm{~s}, 460 \mathrm{~nm}$ light-applications were leading to continuous AP discharge (Fig. 8A). We also tested the capability of transfected neurons to respond to repeated short ( $2 \mathrm{~ms}$ long) flashes of $460 \mathrm{~nm}$ light, a condition previously used in vivo in the amygdala (Johansen et al., 2010). By varying flash frequencies, we observed that most ChR2-expressing neurons were able to strictly follow flashes up to $20 \mathrm{~Hz}$ before exhibiting discharge failures (Fig. 8A). Thus, $20 \mathrm{~Hz}$ trains were retained for in vivo experiments. 
A

\begin{tabular}{|c|c|c|c|c|c|c|c|c|}
\hline \multirow[t]{2}{*}{$\begin{array}{c}\text { Cannula } \\
\text { implantation }\end{array}$} & $\overrightarrow{2 w k s}$ & $\begin{array}{c}\text { Hab. } \\
(\text { context A) }\end{array}$ & $\overrightarrow{24 \mathrm{hrs}}$ & $\begin{array}{l}\text { intra LA } \\
\text { injection }\end{array}$ & $\overrightarrow{0.5-1 \mathrm{hr}}$ & $\begin{array}{c}\text { Cond. } \\
\text { (context A) }\end{array}$ & $\overrightarrow{24 \mathrm{hrs}}$ & $\begin{array}{c}\text { Recall } \\
\text { (context B) }\end{array}$ \\
\hline & & & & Bicuculline & & $5 \times(C S / U S)$ & & \\
\hline
\end{tabular}

\section{B Cannula positions}

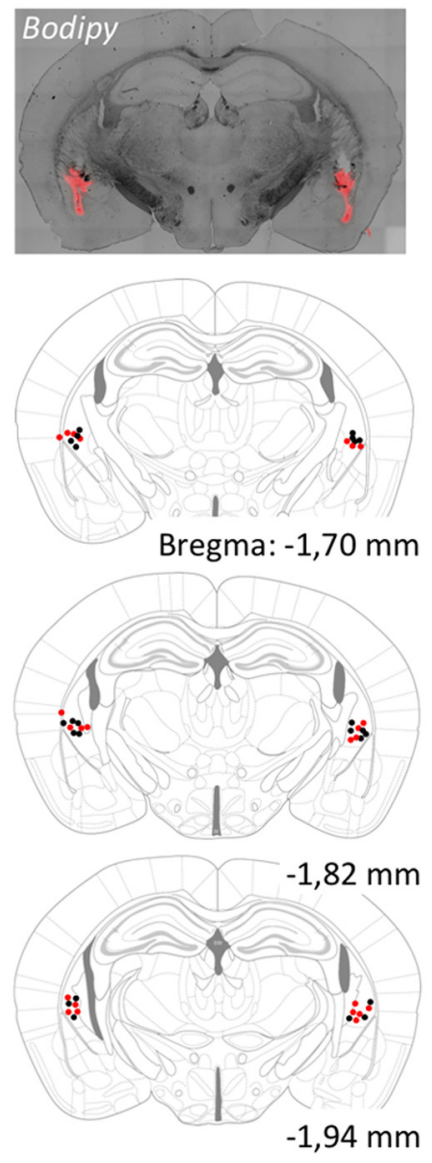

C Locomotor Activity

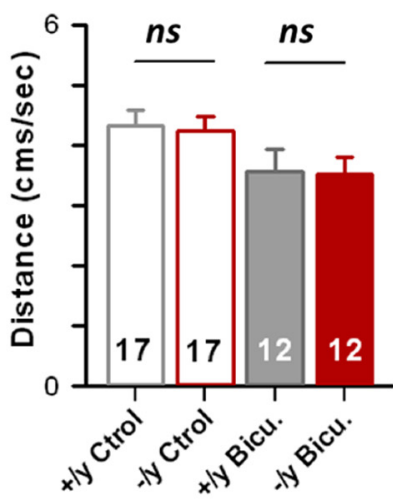

E Recall

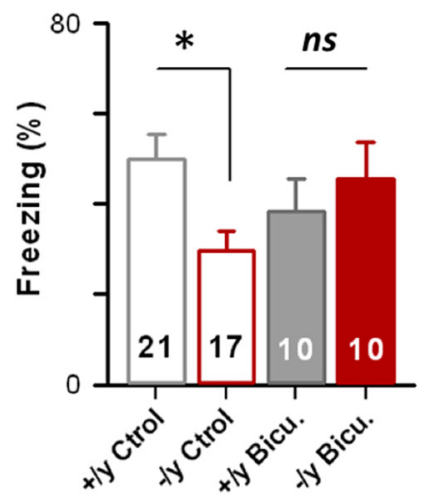

D Conditioning

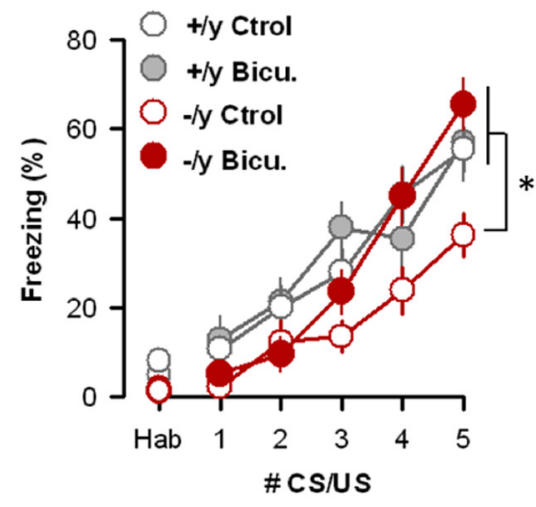

F Thalamic LTP in -/y mice

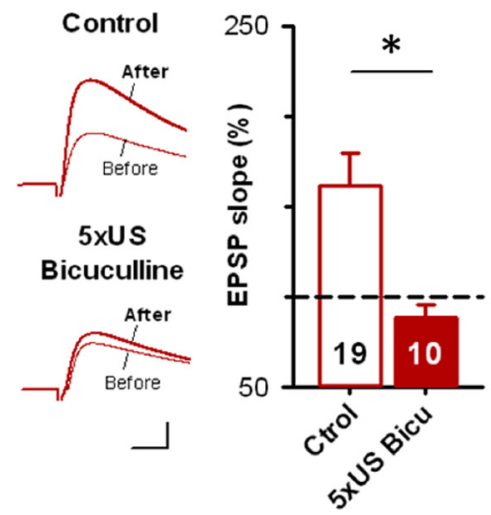

Figure 7. Cued fear learning deficit is restored by preconditioning infusion of the GABAA-R blocker bicuculline in the lateral amygdala. $\boldsymbol{A}$, Experimental paradigm. $\boldsymbol{B}$, Mice were bilaterally implanted above the LA to allow drug application in awake animals just before the fear conditioning. Top, Bodipy ( $500 \mathrm{nl}$ each side) diffusion allowing assessment of drug diffusion in the amygdala region. Bottom, Cannula positions for all $+/ y$ (black dots) and $-/ y$ (red dots) animals considered for statistics. C, Locomotor activity in control and bicuculline-injected animals was measured by tracking of animal movement before the acquisition phase (2 first minutes in Context A). $\boldsymbol{D}, \boldsymbol{E}$, Freezing levels exhibited by bicuculline injected $i / 1$ rapl $1+/ y$ and $-/ y$ animals were measured during conditioning $(\boldsymbol{D})$ and recall $(\boldsymbol{E})$ and compared with nontreated, control K0, and WT mice. $n s$, Not significant. ${ }^{*} p<0.05$. Number of animals is indicated. $\boldsymbol{F}$, Fear learning induced complete thalamo-LA LTP occlusion in bicuculline-treated il/ rap/1 - /y mice. Left, Typical EPSPs recorded before and after pairing in naive and conditioned control (Ctrl) and bicuculline-treated ( $5 \times$ US bicu) K0 mice. Calibration: 4 mV, 5 ms. Right, Mean LTP in illrapl1-/y naive (Ctrl) and conditioned (5 $\times$ US Bicu) bicuculline-treated adult mice. Number of recorded cells is indicated.

Then, a first cohort of 7 ChR2-transduced mice of each genotype was exposed to an associative fear learning (CS/US) + light delivery procedure (Fig. $8 B-D$ ). During conditioning sessions, light applications (unilateral, $460 \mathrm{~nm}, 2 \mathrm{~ms}$ flashes at $20 \mathrm{~Hz}$ during $30 \mathrm{~s}, 6-8 \mathrm{~mW}$ output light power) were repeatedly applied together with $\mathrm{CS}^{+} /$US presentations (Fig. $8 B, C$ ). Importantly, our in vivo light stimulations were proven to be efficient in activating LA neurons as the expression of the activity-reporter C-fos was specifically increased at the illuminated side (data not shown). We then score the freezing levels exhibited by WT and KO mice during $\mathrm{CS}^{+}$presentations within the conditioning phase (Fig. 8 C). Strikingly, both KO and WT cohorts then exhibited very similar freezing levels, comparable with the one observed in WT animals submitted to CS/US pairings (Fig. 1). Interestingly, at the recall test, WT and $\mathrm{KO}$ mice did exhibit a high level of freezing reaction at the $\mathrm{CS}^{+}$presentation (WT light, $44 \pm 13 \%$; KO light, $54 \pm 11 \%$ ), indicating that the improvement of fear memory was maintained (Fig. 8D). However, KO mice also displayed a high degree of generalization (KO light $\mathrm{CS}^{-}, 55 \pm 11 \%$ ), suggesting that CS/US/Light protocol might have abnormally activated the amygdala, leading to a $\mathrm{CS}^{-} / \mathrm{US}$ association. Importantly, we controlled that the light-application effect was depending on the presence of the US (Fig. $8 E-G$ ). Indeed, it has been previously shown that repeated Light/CS presentation could lead to the generation of an associative conditioned response to the CS (Johansen et al., 2010). Thus, in another implanted cohort of $8+/ y$ and $8-/ y$ animals, we could show that the application of $5 \mathrm{CS}^{+} /$Light was not able to induce robust conditioned fear response (Fig. $8 E-G$ ). 
A

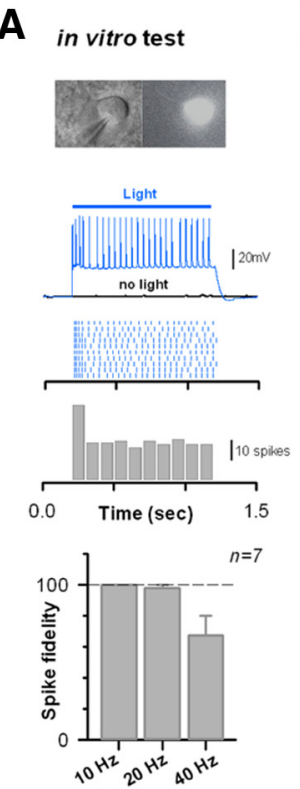

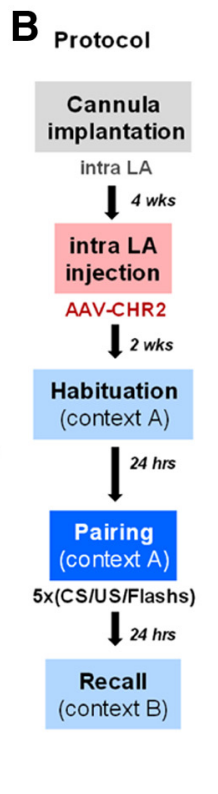
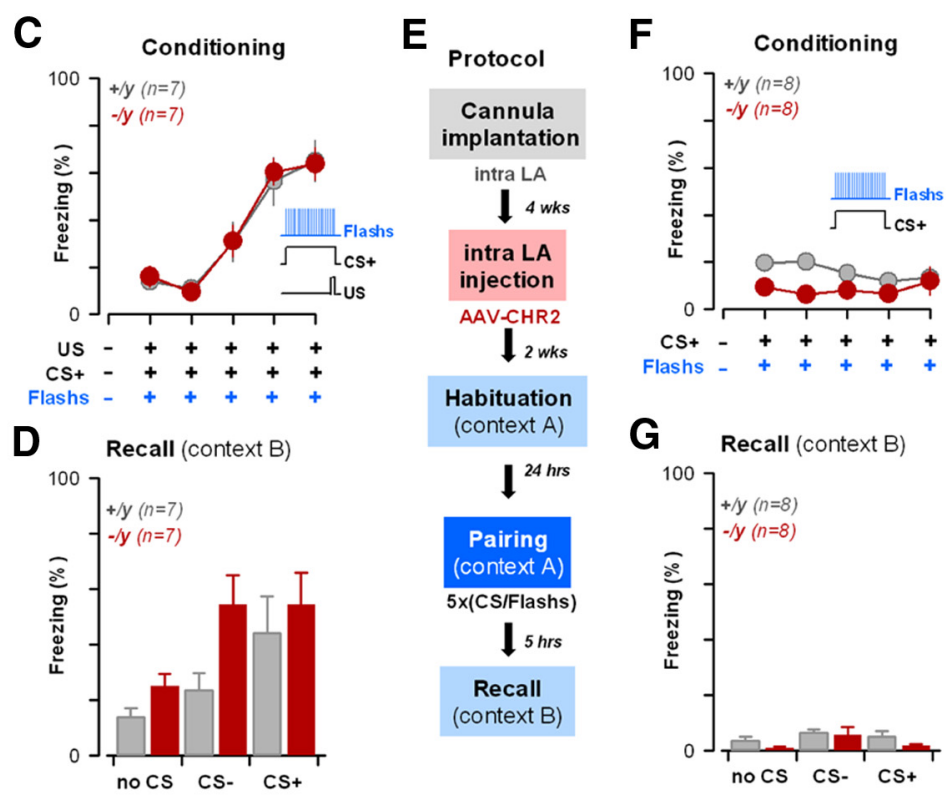

Figure 8. Direct optical activation of $L A$ cells induces comparable associative cued fear learning in normal and il/rap/7-deficient mice. $A$, Light activation of $L A$ neuronal cells using opsin-based strategy. Top, Light flashes (1-s-long, $460 \mathrm{~nm}$ ) induced continuous spiking discharge in AAV-ChR2-transfected LA cells. Bottom, Short flashes (5 ms) were applied at different frequencies, and discharge fidelity was measured. No failure in LA principal cell spiking was observed up to $20 \mathrm{~Hz}$. B. Experimental paradigm used for opsin-based conditioning protocol. It includes chronic cannula implantation, LA infection with AAV-ChR2 constructs, and $460 \mathrm{~nm}$ blue light/CS/US paired applications (see Materials and Methods). C, D, Freezing levels observed during the conditioning $(\boldsymbol{C})$ and the recall $(\boldsymbol{D})$ sessions in $C S / U S /$ light conditioned WT and KO mice. $\boldsymbol{E}-\boldsymbol{G}$, Same presentation as in $\boldsymbol{B}-\boldsymbol{D}$, but for $\mathbf{C S} /$ light pairings.

Collectively, pharmacological (Fig. 7) and opsin-based strategies (Fig. 8) led us to conclude that, once bypassing the requirement of postsynaptic depolarization in LA principal cells, illrapl1-deficient and their WT littermates exhibited comparable amygdala-related learning capabilities. LA-targeted in vivo strategies correcting or bypassing the I/E imbalance at the time of CS/US associations seem successful in normalizing cued fear learning in illrapl1 mutant mice, pointing to the crucial role of this structure in generating the observed deficit.

\section{Discussion}

Using a combined approach at behavioral, cellular, and synaptic levels, we provide a thorough characterization of the consequences of illrapl1 deletion on cued fear related amygdala neuronal networks. Several lines of evidence indicate that the mutation impacts specifically excitatory synapses onto glutamatergic cells, leaving connections to GABAergic cells intact. The working model, strengthened here by in vivo approaches, proposes that local I/E imbalances in amygdala neuronal circuits led to deficits in the acquisition of cued fear memory by lowering LA PN activation, thereby decreasing associative LTP induction. Thus, discrete behavioral deficits may arise from the heterogeneous vulnerability of excitatory synapses to ID gene deficiency.

\section{I/E imbalance and behavioral consequences after illrapl1 deletion}

We propose here that illrapl1 deficiency leads to an I/E imbalance in the LA, perturbing cued fear memory formation, but not cued fear memory expression. Indeed, LA-dedicated experiments aiming at depressing or bypassing the LA-GABAergic system immediately before the CS/US association (i.e., at the exact timing of associative synaptic plasticity induction) were efficiently normalizing for the cued fear deficit during the recall tests (Figs. 7 and 8), long after that correcting treatments were passed. This indicates that, once properly acquired, cued fear memory expression is not impaired in ill rapll-deficient mice. Thus, we propose that, after ill rapl1 mutation, I/E imbalance in LA impairs cued fear memory formation by preventing associative LTP gating at major excitatory entries conveying CS and US modalities (Ehrlich et al., 2009). In addition, our data suggest that LA I/E balance may not be of crucial importance in the reactivation of LA neurons participating to the cued fear memory trace stored in the LA (Han et al., 2009). In this line, former in vivo observations pointed to a depression of the amygdala GABAergic system after cued fear conditioning (Chhatwal et al., 2005). However, because some modalities of the conditioned fear (i.e., $\mathrm{CS}^{+} / \mathrm{CS}-$ discrimination during recall; Fig. 8) and the kinetic of freezing behavior during acquisition (Fig. 7) are not entirely corrected by our in vivo treatments, we cannot exclude that additional mechanisms upstream or downstream to LA integration contribute to the observed cued fear learning phenotype.

The possible impairment of LTP induction in ill rapl1 KO mice is reminiscent of previous observations made on hippocampal memory formation in a Down syndrome mouse model (Kleschevnikov et al., 2004) and more generally in line with an increasing number of reports linking ID/ASD mutations with discrete I/E imbalance in specific networks (Chao et al., 2010; Baroncelli et al., 2011; Pizzarelli and Cherubini, 2011; Yizhar et al., 2011). For Illrapl1-dependent mechanisms, our view is that associative memory formation may be mainly impaired in the brain areas in which (1) the presence of Il1 rapl1 in association with specific molecular partners is crucial for the maintenance/consolidation/function of excitatory synapses onto principal cells (see below), and (2) in which induction of associative LTP is strongly depending on feedforward inhibition and more globally on local I/E balance. 


\section{$\mathrm{I} / \mathrm{E}$ imbalance is induced by the heterogeneous synaptic vulnerability to ill rapll removal}

Interestingly, our results pointed the differential vulnerability of excitatory synapses to ill rapll mutation, especially regarding the identity (e.g., GABAergic or glutamatergic) of the postsynaptic cell (Figs. 3 and 4). Our efforts to better characterize the expression pattern of illrapll led to the identification of a specific but ubiquitous expression of weak levels of the mRNA in most likely all neuron types of the basolateral amygdala complex (Fig. 6). Thereby, the simplistic explanation of illrapl1 - /y phenotype through the differential expression in interneuron and principal cells is ruled out. Interestingly, Ill rapll protein recently emerged through the efforts of several groups as a new trans-synaptic adhesion and signaling molecule entering an heterophilic interaction with presynaptic PTP- $\partial$ (Valnegri et al., 2011; Yoshida et al., 2011). This interaction promotes the aggregation of presynaptic (bassoon and VGLUT1) and postsynaptic (PSD95 and Shank2) proteins at excitatory, but not at inhibitory, contacts in dissociated neuron cultures and in cortical slices (Valnegri et al., 2011; Yoshida et al., 2011). In addition, a recent study proposed that the modulation of RhoA/ROCK signaling by the IL1RAPL1 TIR domain, through an interaction with Mcf2l (Hayashi et al., 2013), mediates both IL1RAPL1-mediated spinogenesis and control of AMPAR trafficking (Hayashi et al., 2013), possibly linking functional and morphological phenotypes. In the amygdala, feedforward inhibition is elicited through the activation of AMPAR- and NMDAR-containing postsynapses on low-spiny GABAergic interneurons (Szinyei et al., 2000, 2003; Spampanato et al., 2011). Taking this into account, one can imagine that ill rapll mutation does not affect interneurons the same way it does principal cells. In this line, recent work strikingly brought evidence for a mirror role of the postsynaptic protein Erbin only at excitatory synapse formed with GABAergic neurons (Tao et al., 2013). Further work will be necessary to understand whether there is a causal relationship between the absence of dendritic spine and the absence of functional consequence of illrapll mutation. Indeed, one may anticipate that the impact of many ID gene mutations may not be ubiquitous at central synapses and that similar functional I/E imbalance generated by this heterogeneity may also be found in other ID models.

Recently, the emergence of several families of trans-synaptic adhesion molecules important for synapse specification raised a lot of interest by pointing to an unexpected possible wealth of heterogeneity in synaptic functions and plasticity (McMahon and Díaz, 2011; Siddiqui and Craig, 2011). Beyond the diversity in genes, many splice variants were also shown to occur at these loci (Missler and Südhof, 1998a). Additionally, secreted binding partners (e.g., neurexophilins) exist that can alter trans-synaptic adhesions (Missler and Südhof, 1998b). More striking is the activity-dependent regulation of neurexin1 binding through alternative splicing (Iijima et al., 2011). Thus, the synaptic code determining the balance of expression of this mixture of molecules at a given synapse is of key importance to understand how complex brain circuits are wired. Clearly, our work points to the functional heterogeneity of excitatory synaptic inputs involved in the fulfillment of complex behavioral functions. Although ill rapl1 mRNA seems to be expressed at all cell types of amygdala, additional experiments will be required to understand the molecular rational behind the differential vulnerability of excitatory synapses to ill rapll deletion.

We further show that deletion of ill rapl1 results in fading of excitatory transmission and morphological impairments at thalamo-LA Vglut2-PSD95 (Fig. 5). Indeed, medial geniculate medial part and postintralaminar thalamic nuclei that project to LA both express robust levels of vglut 2 mRNA (Fremeau et al., 2001). Although we bring here convincing in situ hybridization of ill rapl1 mRNA, the lack of comprehensive morphological description of the Illrapll and PTP- $\partial$ distributions hampers our ability to fully overview the system we dissected. Nevertheless, our data suggest that either the functional Il1rapl1/PTP- $\partial$ complex is formed mainly at thalamo-LA synapses, or that it is formed at all excitatory synapses but is only critical at the thalamo-LA connection. In the latter scenario, functional redundancy may blur the phenotype of the deletion at most other synapses. Alternatively, we cannot rule out that our observations result from Il1rapl1-induced extrasynaptic alterations that in turn unravel existing presynaptic heterogeneity to neuromodulation. Indeed, Chu et al. (2012) recently illustrated the target-specific suppression of GABAergic transmission by dopamine.

Interestingly, we did not observe a loss of dendritic spines in LA pyramidal neurons from ill rapl1 -/y animals (Fig. 5A), somehow contrasting with the I/O curves showing a functional disappearance of these long range connections (Fig. 3). Further, we also observed very little effects of the mutation on miniature EPSCs recorded in LA principal cells (Fig. 5). This paradox opens the interesting possibility that the mutation introduces a switch from long range to local synaptic connectivity, a model also proposed for neurodevelopmental disorders (Geschwind and Levitt, 2007). The neurodevelopmental disorder theory states that neurons are hyperconnected at the local network level, but in contrast, show decreased long-range connectivity between cortical brain circuits. For example, prominent hyperconnectivity was recently shown in local medial prefrontal cortical networks of a genetic mouse model for intellectual disability and autism (TestaSilva et al., 2012). Addressing this question would require assessment of LA-LA principal cell connectivity in illrapll $\mathrm{KO}$ mice. Hyperconnectivity observations would then redefine illrapl1 mutations as causing a neurodevelopmental disorder syndrome.

In conclusion, our work unravels heterogeneity in synaptic dependency to Ill rapll function and its role in the fine-tuning of I/E balance in discrete circuits of the brain. We suggest that constitutive absence of Illrapll disrupts this balance, possibly explaining the deficit in LTP induction in vivo and the behavioral deficits observed in $\mathrm{KO}$ mice. Beyond providing a first mechanistic explanation to I/E imbalance, a phenotype frequently associated with cognitive disorders, our results force one to not only examine the impact of a particular ID mutation onto a single synaptic type but rather to consider all physiological determinants driving a functional neuronal circuit. Conversely, the use of ID/ASD models may also allow identifying new sources of behaviorally relevant synaptic heterogeneity.

\section{References}

Baroncelli L, Braschi C, Spolidoro M, Begenisic T, Maffei L, Sale A (2011) Brain plasticity and disease: a matter of unhibition. Neural Plast 2011: 1-11. CrossRef Medline

Berlau DJ, McGaugh JL (2006) Enhancement of extinction memory consolidation: the role of the noradrenergic and GABAergic systems within the basolateral amygdala. Neurobiol Learn Mem 86:123-132. CrossRef Medline

Bissière S, Humeau Y, Lüthi A (2003) Dopamine gates LTP induction in lateral amygdala by suppressing feedforward inhibition. Nat Neurosci 6:587-592. CrossRef Medline

Bliss TV, Lomo T (1973) Long-lasting potentiation of synaptic transmission in the dentate area of the anaesthetized rabbit following stimulation of the perforant path. J Physiol 232:331-356. Medline

Carrié A, Jun L, Bienvenu T, Vinet MC, McDonell N, Couvert P, Zemni R, Cardona A, Van Buggenhout G, Frints S, Hamel B, Moraine C, Ropers 
HH, Strom T, Howell GR, Whittaker A, Ross MT, Kahn A, Fryns JP, Beldjord C, et al. (1999) A new member of the IL-1 receptor family highly expressed in hippocampus and involved in X-linked mental retardation. Nat Genet 23:25-31. CrossRef Medline

Chao HT, Chen H, Samaco RC, Xue M, Chahrour M, Yoo J, Neul JL, Gong S, Lu HC, Heintz N, Ekker M, Rubenstein JL, Noebels JL, Rosenmund C, Zoghbi HY (2010) Dysfunction in GABA signalling mediates autism-like stereotypies and Rett syndrome phenotypes. Nature 468: 263-269. CrossRef Medline

Chhatwal JP, Myers KM, Ressler KJ, Davis M (2005) Regulation of gephyrin and GABAA receptor binding within the amygdala after fear acquisition and extinction. J Neurosci 25:502-506. CrossRef Medline

Chu HY, Ito W, Li J, Morozov A (2012) Target-specific suppression of GABA release from parvalbumin interneurons in the basolateral amygdala by dopamine. J Neurosci 32:14815-14820. CrossRef Medline

Dani VS, Chang Q, Maffei A, Turrigiano GG, Jaenisch R, Nelson SB (2005) Reduced cortical activity due to a shift in the balance between excitation and inhibition in a mouse model of Rett syndrome. Proc Natl Acad Sci U S A 102:12560-12565. CrossRef Medline

Ehrlich I, Humeau Y, Grenier F, Ciocchi S, Herry C, Lüthi A (2009) Amygdala inhibitory circuits and the control of fear memory. Neuron 62:757-771. CrossRef Medline

Fremeau RT Jr, Troyer MD, Pahner I, Nygaard GO, Tran CH, Reimer RJ, Bellocchio EE, Fortin D, Storm-Mathisen J, Edwards RH (2001) The expression of vesicular glutamate transporters defines two classes of excitatory synapse. Neuron 31:247-260. CrossRef Medline

Gabernet L, Jadhav SP, Feldman DE, Carandini M, Scanziani M (2005) Somatosensory integration controlled by dynamic thalamocortical feedforward inhibition. Neuron 48:315-327. CrossRef Medline

Gambino F, Pavlowsky A, Béglé A, Dupont JL, Bahi N, Courjaret R, Gardette R, Hadjkacem H, Skala H, Poulain B, Chelly J, Vitale N, Humeau Y (2007) IL1-receptor accessory protein-like 1 (IL1RAPL1), a protein involved in cognitive functions, regulates $\mathrm{N}$-type $\mathrm{Ca}^{2+}$-channel and neurite elongation. Proc Natl Acad Sci U S A 104:9063-9068. CrossRef Medline

Gambino F, Kneib M, Pavlowsky A, Skala H, Heitz S, Vitale N, Poulain B, Khelfaoui M, Chelly J, Billuart P, Humeau Y (2009) IL1RAPL1 controls inhibitory networks during cerebellar development in mice. Eur J Neurosci 30:1476-1486. CrossRef Medline

Gambino F, Khelfaoui M, Poulain B, Bienvenu T, Chelly J, Humeau Y (2010) Synaptic maturation at cortical projections to the lateral amygdala in a mouse model of Rett syndrome. PLoS One 5:e11399. CrossRef Medline

Geschwind DH, Levitt P (2007) Autism spectrum disorders: developmental disconnection syndromes. Curr Opin Neurobiol 17:103-111. CrossRef Medline

Han JH, Kushner SA, Yiu AP, Hsiang HL, Buch T, Waisman A, Bontempi B, Neve RL, Frankland PW, Josselyn SA (2009) Selective erasure of a fear memory. Science 323:1492-1496. CrossRef Medline

Hayashi T, Yoshida T, Ra M, Taguchi R, Mishina M (2013) IL1RAPL1 associated with mental retardation and autism regulates the formation and stabilization of glutamatergic synapses of cortical neurons through RhoA signaling pathway. PLoS One 8:e66254. CrossRef Medline

Herry C, Ciocchi S, Senn V, Demmou L, Müller C, Lüthi A (2008) Switching on and off fear by distinct neuronal circuits. Nature 454:600-606. CrossRef Medline

Hong I, Kim J, Lee J, Park S, Song B, Kim J, An B, Park K, Lee HW, Lee S, Kim H, Park SH, Eom KD, Lee S, Choi S (2011) Reversible plasticity of fear memory-encoding amygdala synaptic circuits even after fear memory consolidation. PLoS One 6:e24260. CrossRef Medline

Humeau Y, Herry C, Kemp N, Shaban H, Fourcaudot E, Bissière S, Lüthi A (2005) Dendritic spine heterogeneity determines afferent-specific hebbian plasticity in the amygdala. Neuron 45:119-131. CrossRef Medline

Humeau Y, Reisel D, Johnson AW, Borchardt T, Jensen V, Gebhardt C, Bosch V, Gass P, Bannerman DM, Good MA, Hvalby $\varnothing$, Sprengel R, Lüthi A (2007) A pathway-specific function for different AMPA receptor subunits in amygdala long-term potentiation and fear cconditioning. J Neurosci 27:10947-10956. CrossRef Medline

Humeau Y, Gambino F, Chelly J, Vitale N (2009) X-linked mental retardation: focus on synaptic function and plasticity. J Neurochem 109: 1-14. CrossRef Medline

Iijima T, Wu K, Witte H, Hanno-Iijima Y, Glatter T, Richard S, Scheiffele P
(2011) SAM68 regulates neuronal activity-dependent alternative splicing of neurexin-1. Cell 147:1601-1614. CrossRef Medline

Johansen JP, Hamanaka H, Monfils MH, Behnia R, Deisseroth K, Blair HT, LeDoux JE (2010) Optical activation of lateral amygdala pyramidal cells instructs associative fear learning. Proc Natl Acad Sci U S A 107:1269212697. CrossRef Medline

Kleschevnikov AM, Belichenko PV, Villar AJ, Epstein CJ, Malenka RC, Mobley WC (2004) Hippocampal long-term potentiation suppressed by increased inhibition in the Ts65Dn mouse, a genetic model of Down syndrome. J Neurosci 24:8153-8160. CrossRef Medline

LeDoux JE (2000) Emotion circuits in the brain. Annu Rev Neurosci 23: 155-184. CrossRef Medline

Maren S (2005) Synaptic mechanisms of associative memory in the amygdala. Neuron 47:783-786. CrossRef Medline

McDonald AJ (1982) Neurons of the lateral and basolateral amygdaloid nuclei: a Golgi study in the rat. J Comp Neurol 212:293-312. CrossRef Medline

McMahon SA, Díaz E (2011) Mechanisms of excitatory synapse maturation by trans-synaptic organizing complexes. Curr Opin Neurobiol 21:221-227. CrossRef Medline

Missler M, Südhof TC (1998a) Neurexins: three genes and 1001 products. Trends Genet 14:20-26. CrossRef Medline

Missler M, Südhof TC (1998b) Neurexophilins form a conserved family of neuropeptide-like glycoproteins. J Neurosci 18:3630-3638. Medline

Moutsimilli L, Farley S, Dumas S, El Mestikawy El S, Giros B, Tzavara ET (2005) Selective cortical VGLUT1 increase as a marker for antidepressant activity. Neuropharmacology 49:890-900. CrossRef Medline

Pavlowsky A, Gianfelice A, Pallotto M, Zanchi A, Vara H, Khelfaoui M, Valnegri P, Rezai X, Bassani S, Brambilla D, Kumpost J, Blahos J, Roux MJ, Humeau Y, Chelly J, Passafaro M, Giustetto M, Billuart P, Sala C (2010) A postsynaptic signaling pathway that may account for the cognitive defect due to IL1RAPL1 mutation. Curr Biol 20:103-115. CrossRef Medline

Pavlowsky A, Chelly J, Billuart P (2011) Emerging major synaptic signaling pathways involved in intellectual disability. Mol Psychiatry 17: 682-693. CrossRef Medline

Piton A, Michaud JL, Peng H, Aradhya S, Gauthier J, Mottron L, Champagne $\mathrm{N}$, Lafrenière RG, Hamdan FF, Hamdan FF, Joober R, Fombonne E, Marineau C, Cossette P, Dubé MP, Haghighi P, Drapeau P, Barker PA, Carbonetto S, Rouleau GA (2008) Mutations in the calcium-related gene IL1RAPL1 are associated with autism. Hum Mol Genet 17:39653974. CrossRef Medline

Pizzarelli R, Cherubini E (2011) Alterations of GABAergic signaling in autism spectrum disorders. Neural Plast 2011:1-12. CrossRef Medline

Pouille F, Scanziani M (2001) Enforcement of temporal fidelity in pyramidal cells by somatic feed-forward inhibition. Science 293:1159-1163. CrossRef Medline

Purpura DP (1974) Dendritic spine "dysgenesis" and mental retardation. Science 186:1126-1128. CrossRef Medline

Rodriguez A, Ehlenberger DB, Dickstein DL, Hof PR, Wearne SL (2008) Automated three-dimensional detection and shape classification of dendritic spines from fluorescence microscopy images. PLoS One 3:e1997. CrossRef Medline

Rosenkranz JA, Grace AA (2002) Dopamine-mediated modulation of odour-evoked amygdala potentials during Pavlovian conditioning. Nature 417:282-287. CrossRef Medline

Rumpel S, LeDoux J, Zador A, Malinow R (2005) Postsynaptic receptor trafficking underlying a form of associative learning. Science 308:83-88. CrossRef Medline

Sanger DJ, Joly D (1985) Anxiolytic drugs and the acquisition of conditioned fear in mice. Psychopharmacology (Berl) 85:284-288. CrossRef Medline

Siddiqui TJ, Craig AM (2011) Synaptic organizing complexes. Curr Opin Neurobiol 21:132-143. CrossRef Medline

Sosulina L, Meis S, Seifert G, Steinhäuser C, Pape HC (2006) Classification of projection neurons and interneurons in the rat lateral amygdala based upon cluster analysis. Mol Cell Neurosci 33:57-67. CrossRef Medline

Sosulina L, Graebenitz S, Pape HC (2010) GABAergic interneurons in the mouse lateral amygdala: a classification study. J Neurophysiol 104:617626. CrossRef Medline

Spampanato J, Polepalli J, Sah P (2011) Interneurons in the basolateral amygdala. Neuropharmacology 60:765-773. CrossRef Medline

Szinyei C, Heinbockel T, Montagne J, Pape HC (2000) Putative cortical and 
thalamic inputs elicit convergent excitation in a population of GABAergic interneurons of the lateral amygdala. J Neurosci 20:8909-8915. Medline

Szinyei C, Stork O, Pape HC (2003) Contribution of NR2B subunits to synaptic transmission in amygdaloid interneurons. J Neurosci 23:25492556. Medline

Tamamaki N, Yanagawa Y, Tomioka R, Miyazaki J, Obata K, Kaneko T (2003) Green fluorescent protein expression and colocalization with calretinin, parvalbumin, and somatostatin in the GAD67-GFP knock-in mouse. J Comp Neurol 467:60-79. CrossRef Medline

Tao Y, Chen YJ, Shen C, Luo Z, Bates CR, Lee D, Marchetto S, Gao TM, Borg JP, Xiong WC, Mei L (2013) Erbin interacts with TARP $\gamma$-2 for surface expression of AMPA receptors in cortical interneurons. Nat Neurosci 16:290-299. CrossRef Medline

Testa-Silva G, Loebel A, Giugliano M, de Kock CP, Mansvelder HD, Meredith RM (2012) Hyperconnectivity and slow synapses during early development of medial prefrontal cortex in a mouse model for mental retardation and autism. Cereb Cortex 22:1333-1342. CrossRef Medline

Vaillend C, Poirier R, Laroche S (2008) Genes, plasticity and mental retardation. Behav Brain Res 192:88-105. CrossRef Medline
Valnegri P, Montrasio C, Brambilla D, Ko J, Passafaro M, Sala C (2011) The $\mathrm{X}$-linked intellectual disability protein IL1RAPL1 regulates excitatory synapse formation by binding PTP and RhoGAP2. Hum Mol Genet 20:47974809. CrossRef Medline

van Bokhoven H (2011) Genetic and epigenetic networks in intellectual disabilities. Annu Rev Genet 45:81-104. CrossRef Medline

Yizhar O, Fenno LE, Prigge M, Schneider F, Davidson TJ, O'Shea DJ, Sohal VS, Goshen I, Finkelstein J, Paz JT, Stehfest K, Fudim R, Ramakrishnan C, Huguenard JR, Hegemann P, Deisseroth K (2011) Neocortical excitation/inhibition balance in information processing and social dysfunction. Nature 477:171-178. CrossRef Medline

Yoshida T, Yasumura M, Uemura T, Lee SJ, Ra M, Taguchi R, Iwakura Y, Mishina M (2011) IL-1 receptor accessory protein-like 1 associated with mental retardation and autism mediates synapse formation by transsynaptic interaction with protein tyrosine phosphatase. J Neurosci 31: 13485-13499. CrossRef Medline 